\title{
The marbles of the basilica of Ascalon: another example of the Severan building projects
}

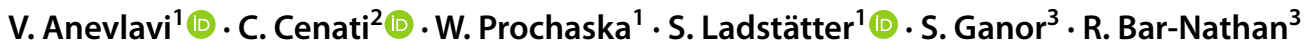

Received: 25 November 2021 / Accepted: 5 February 2022 / Published online: 1 March 2022

(c) The Author(s) 2022

\begin{abstract}
This paper presents the research conducted on the origin of the white marble architecture of the basilica of Ascalon (Israel). The basilica is located in the civic centre of the Roman city of Ascalon and it is one of the relatively few known monumental buildings of Roman Palestine. The various construction phases of the basilica are dated from the first century BC to the third century AD. As Israel has no sources of marble, this paper explores the origin of the white marble that was used for several architectural elements such as bases, columns, capitals, and figurative pilasters to identify their provenance. The methodology includes petrographic studies, chemical and isotopic analyses, and chemical analyses of inclusion fluids and extractable salts (crush-leach analyses) of the marble. The results demonstrate that the imported marble highlights the wide extent of connectivity and interregional trade in the region. Some of the main sources of building materials used in the construction programme of this basilica originate from famous supra-regional quarries such as Prokonnesos and Thasos, and different quarries on the island of Lesbos. The similarities between the Severan basilica in Ascalon and the contemporary building in Leptis Magna are also discussed in this paper. In combination with the absence of a built-up port in the ancient city of Ascalon, these results also provide important information on the economy of Roman Palestine, transportation networks, and the logistical organisation of large-scale building programmes.
\end{abstract}

Keywords Ascalon $\cdot$ Basilica $\cdot$ Roman period $\cdot$ Severan architecture $\cdot$ Israel $\cdot$ White marble $\cdot$ Marble provenance

V. Anevlavi

vasiliki.anevlavi@oeaw.ac.at

C. Cenati

chiara.cenati@univie.ac.at

W. Prochaska

walter.prochaska@oeaw.ac.at

S. Ladstätter

sabine.ladstaetter@oeaw.ac.at

S. Ganor

saarg@israntique.org.il

R. Bar-Nathan

rachel@israntique.org.il

1 Austrian Archaeological Institute, Austrian Academy of Sciences, Vienna, Austria

2 Institut für Alte Geschichte und Altertumskunde, Papyrologie und Epigraphik, Universität Wien, Vienna, Austria

3 Israel Antiquities Authority, Omar High-Tech Park, Omar Industrial Park, Omer, Israel

\section{Introduction: White marble in Roman Palestine}

Although Israel has no marble quarries of its own, there are plenty of marble objects and buildings in the region that are made of this special raw material. The use of marble in Roman Palestine is mentioned for the first time by Flavius Josephus (Fisher and Stein 1994; Fischer 2007), who claims in his Bellum Iudaicum that marble was systematically used in Herod's building projects (Bellum Iudaicum 1.21.2, 1.21.10-11, 4.9.7, 5.4.4, 5.5.2; see Fischer and Stein 1994). This could be a case of confusion between marble and limestone in ancient sources, or, more likely, the result of a slightly different meaning of the word marmor/ $\mu \alpha \rho \mu \alpha$ ó $\rho$ in Latin and Greek (Russell 2013). As we will demonstrate in this paper, it is particularly difficult in some cases to distinguish between marble and limestone solely on chemical and isotopic analyses. This difference was evidently not relevant in ancient languages that would have used the same word to identify marble and very bright, light-coloured or polished limestone (Fischer and Stein 1994, pp. 80). 
King Herodes rebuilt the Hellenistic cities that had been destroyed by the Hasmoneans and undertook the largest building programme before the setup of the Roman province (Fischer 2019, pp. 17-22). The Herodian buildings were not made of white marble, as this material is not archaeologically attested in any building of this phase. Palestinian centres and cities like Baalbek and Palmyra mainly used local limestone (Fischer 2007). But the use of polished limestone shows that Herodian architecture and furnishing were already oriented towards Hellenistic-Roman tastes. Marble seems to have been introduced in this region as an import only after Palestine entered the Roman provincial commercial network. Between the end of the first and the beginning of the second century $\mathrm{AD}$, marble started to replace local limestone in new building constructions. In this time, marble was not just seen as a luxury material, but it represented the symbol of the new relationship between Rome and the province and a clear sign of the adhesion to the imperial power (on this topic, see Pensabene 2006, 2013; Fischer 2019). Becoming Roman and displaying the Roman way of life thus implied the use of marble, both coloured and white. The massive importation of marble to Palestine for architecture, sculpture, and sarcophagi began with the great urban renewal at the end of the second century because of the new Antonines building policy. This included the building of temples for the imperial cult, thermae, palaestrae, and aqueducts across the province. During the Severan period, some centres achieved the rank of cities or changed their status and were adorned with new monumental architecture (Fischer 2007, pp. 249). In general, marble was not commonly used in Roman Palestine especially when compared to its use in other provinces. The stone was used only selectively and it was imported from a few quarries.

Major marble building programmes were undertaken in Caesarea Maritima the province's largest importer in Ascalon and in Scythopolis. Ascalon and Caesarea were the two cities through which marble reached the province. Caesarea had the largest harbour in the province, while no harbour has been discovered along the coast of Ascalon (Fischer 2007). From Caesarea, marble reached Scythopolis through terrestrial networks. Scythopolis was $70 \mathrm{~km}$ inland but connected to Caesarea through a direct road (Fischer 1995). Known today as Beth Shean, Scythopolis was a commercial centre and the main city of the Decapolis. Here, imported marble from Prokonnesos, Thasos, Aphrodisias, and Dokimeion was used with local limestone for sculptural and architectural decoration in Roman times (Romano and Fischer 2009).

Architectural studies on Roman Palestine indicated that complete veneer façades were made of marble, while both marble and local limestone were used for other elements such as bases, pedestals, and columns. This building and architectural practice is commonly found in North Africa
(Leptis Magna) (see Bruno and Bianchi 2015), and in some areas of Greece (Corinth) (Fischer 2007, pp. 250). It is believed that various production centres were providing Roman Palestine with rough-shaped or semi-finished products, while the final details and decoration were done by the itinerant or local marmorarii (Fischer 2007, pp. 250).

The use of white and coloured marble in Roman Palestine was not limited to buildings. Other types of artefacts also show connections between Palestine and East Mediterranean marble sources. Figurative sculpture is, with few exceptions, absent during the Herodian and Hellenistic period (Fischer 2019, pp. 19-22). During Roman times, statues are almost always imported, and such imports increased during the Antonine period (Fischer 2019, p. 25). Around 40\% of marble sculptures were found in Caesarea, and they decorated buildings for the imperial cult like the temple of Augustus and Roma, which is still preserved, and the Tibereum and Hadrianeum, whose existence is also attested (Dirven 2011, pp. 149-153; Fischer 2019). Further examples of imported marble sculptures are found in the sanctuary of Pan in Caesarea Philippi/Panias. Archaeometric analyses (isotope analysis) of 15 sculptures revealed that the marble source may have come from Asia Minor or Greece. However, unequivocal results cannot be obtained (Friedland 2012). Recent investigations on a Roman portrait of Alexander the Great from Beth Shean revealed that the marble originates from Aphrodisias, Asia Minor (Romano et al. 2021). During the second and third centuries, marble sarcophagi were imported into Roman Palestine and they were used especially in towns on the coast (Fischer 2007, pp. 252). The import of these semi-finished artefacts must have affected the local limestone production, exactly as is the case for architectural elements and statuary.

Marble artefacts in Palestine do not show any particular local characteristics; on the contrary, they have similar stylistic features with marble types from the Eastern Mediterranean. An overall tendency to reuse marble artefacts due to the difficulty to access this kind of stone can be noticed throughout the province and especially in Caesarea, where inscriptions are often engraved on reused objects (Burrell 2018). After a decrease during the third and the fourth centuries, a revival of marble imports began under Theodosius II, and continued in the fifth and sixth centuries. In Late Antiquity, marble reached more centres than before, but it was imported in smaller quantities (Fischer 1998). ${ }^{1}$

Since the importation of marble into the province is a fact, scholars and scientists have tried, in the past, to establish the origin of this material in Palestine. Analysis conducted by

\footnotetext{
${ }^{1}$ Fischer discusses the place of marble in the Levant more generally and the Land of Israel more specifically in three publications aimed at this region (Fischer 1998, 2002, 2019).
} 
Z. Pearl and M. Magaritz revealed that various architectural elements from a range of cities (Scythopolis, Caesarea) were mainly made of Prokonnesos (Marmara marble), while marble from Paros, Pentelikon, Thasos, Hymettus, and perhaps Carrara were used for the sculptures (Pearl and Magaritz 1991). It can also be added the quarry of Euromos in Caria to these marble sources (Burrell 2018). According to M. Fischer, about $50-60 \%$ of the marble in Palestine comes from Prokonnesos, with $80 \%$ of the architectural pieces considered to be Prokonnesian, while Greek marble is rarer (Fischer 2007, pp. 254).

\section{Ascalon and its basilica}

Ascalon was one of the main centres of the south-Mediterranean coast of Palestine. It was located on a very favourable position on the via Maris, the street that connected Africa with Syria and Asia (on the road system of Roman Palestine, see Safrai 1994, pp. 275-176). The centre was never included in the kingdom of Herodes. Nevertheless, this king had a very special relationship with the city, building a basilica, baths, fountains, and stoai across the city (Flavius Josephus, Bellum Iudaicum, 1.422-425; Antiquitates Iudaicae, 15.328-330). In $70 \mathrm{AD}$, Ascalon became part of the province of Iudaea as a "free city" (Claudius Ptolemy, Geography, 5.15.1; Pliny the Elder, Naturalis Historia, 5.68). Ascalon flourished in the second into the beginning of the third century AD under the Antoninii and Severi. The revival of the city and reorganisation of the urban plan was also promoted during the Severan dynasty. ${ }^{2}$

No structured harbour has been yet discovered on the coast of ancient Ascalon (Galili et al. 2001; Stager et al. 2006, pp. 67-100). The morphology of this part of the coast seems to not have been suitable for a constructed port, but it is possible that one, yet undiscovered, was situated in the north or south part of the city. ${ }^{3}$ The existence of a port is mentioned in only one ancient written source of the second century BC (Letter of Aristeas 115) and appears again in the twelfth century, when William of Tyre writes that he visited Ascalon and that the city had no safe harbour (Historia Rerum in Partibus Transmarinis Gestarum, 17.22). However, the apparent absence of a safe built-up basin did not prevent the city from flourishing in trade. During the Roman era and until Byzantine times, Ascalon was at the centre of Mediterranean trade networks (Fig. 1) (Safrai 1994, pp. 271-274; Kislinger 1999; Johnson 2008) and

\footnotetext{
${ }^{2}$ For a new overview on the history of Ascalon and its excavations, see Dell'Acqua (2021b).

${ }^{3}$ On the existence of a harbour in Ascalon or nearby, see Dell'Acqua (2021b).
}

became particularly famous for its wine (Piéri 2005). One inscription from Ascalon (Corpus inscriptionum Iudaeae/ Palaestinae 3, nr. 2342) mentions the captain of a ship who was a member of a guild that probably traded wine between Rome and the province in the second century AD. In the anonymous Description of the World written in Late Antiquity (Expositio totius Mundi, 29), Ascalon and Gaza are described as notable cities, particularly active and rich in trade. The writer Ammianus Marcellinus (14.8.11) lists Ascalon among the outstanding cities in Palestine. From papyri, it is known that the city of Ascalon was also visited between 320 and 324 AD by Theophanes, an Egyptian businessman (Matthews 2006). The sea transport from and to the city is archaeologically and epigraphically attested. Many anchors and inscribed weights (Corpus inscriptionum Iudaeae/Palaestinae 3, pp. 240-241 and nr. 2383-2386) have been found in the sea, demonstrating that bigger ships moored 300-600 $\mathrm{m}$ from the coast and their cargoes were unloaded into smaller boats that transported the goods to the shore. The imported marble used in Ascalon reached the city likely together with specialised stonemasons, who were in charge of finishing and polishing the artefacts. The use of marble in large-scale building construction, such as the basilica, is evidence of the adaptation of Roman representative architecture and the embedding of the province of Palestine in a circum-Mediterranean cultural koiné.

The basilica of Ascalon is one of the largest buildings of Roman Palestine. ${ }^{4}$ Excavations at the Odeon undertaken in 2008-2012 by the Leon Levy Expedition brought to light new information about the different architectural phases of the complex, the surrounding buildings, the urban development, and organisation of the city (Boehm et al. 2016). New excavations have been carried out in the last few years by the Israel Antiquities Authority (Ganor and Bar-Nathan 2021).

Between the end of the second and the beginning of the first century $\mathrm{BC}$, the area of the basilica was occupied by a monumental rectangular building with a porticus. The first construction phase of the basilica of Ascalon can be dated between the first century BC and the first century AD. In this phase, the apsidal room behind the basilica had the function of bouleuterion/curia. During the reign of Septimius Severus, the basilica and the bouleuterion/curia complex were renovated, and the structure of the basilica was significantly changed. The apsidal room was monumentalised and turned in the form of an odeion, which served as a multifunctional structure. In the late Byzantine period, parts of the basilica complex were reused and the whole area was

\footnotetext{
4 The coordinates of the Basilica are $31^{\circ} 39^{\prime} 35.496^{\prime \prime}(\mathrm{N})$, $34^{\circ} 32^{\prime} 48.156^{\prime \prime}$ (E). The information was collected during the sampling campaign of 2019, with the use of a GPS device.
} 


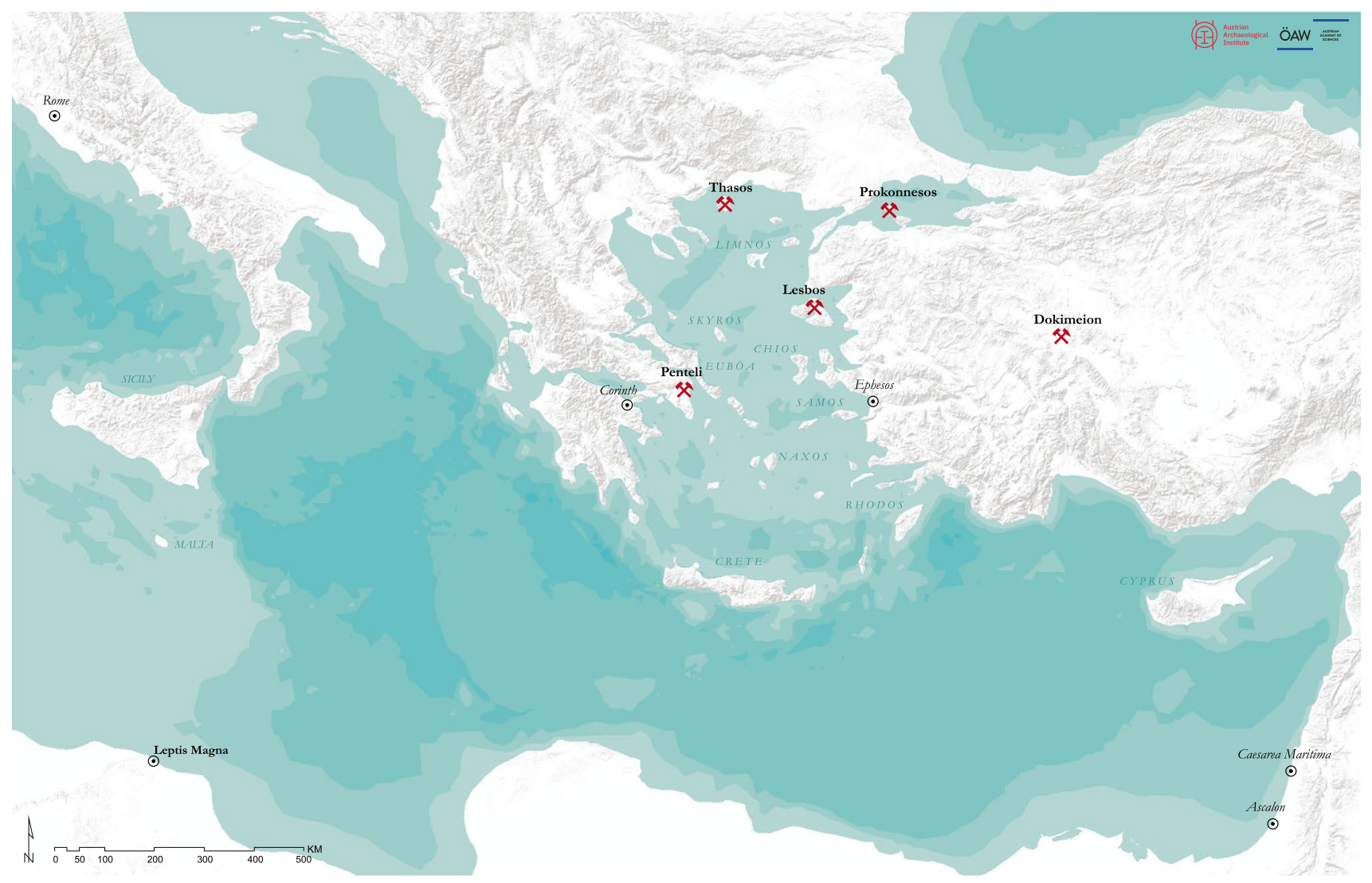

Fig. 1 Map of Eastern Mediterranean; with black colour, the site of Ascalon is indicated; with red colours, the relevant with the project quarries are marked (N. Math, ÖAI/ÖAW)

turned into a residential complex (Boehm et al. 2016, pp. 280).

The architectural elements which were made of marble and survived at the archaeological site belong mainly to the Severan phase. ${ }^{5}$ The main floor of the three-nave building was built on monolithic grey granite columns from the Troad, while other columns are made of Pavonazzetto marble from Dokimeion (Fischer 2010; Dell'Acqua 2021a). Particularly significant are the figurative pilasters, which likely decorated the façade of the basilica, maybe on the side facing the Forum. ${ }^{6}$ These likely numbered more than four, since recent excavations unearthed fragments of new pilasters that were analysed in the present paper. ${ }^{7}$ Three of them represent a Victory/Nike, and in the best-preserved example, Nike is standing on a globe supported by Atlas. The main figure of

\footnotetext{
5 The architectural decoration of the basilica has been recently studied by Dell'Acqua (2021a).

${ }^{6}$ See Dell'Acqua (2021a). It is unlikely that they constituted the monumental entrance to the odeum from the side of the basilica as indicated in Boehm et al. (2006), 311.

7 At time of Fischer (1995) and Boehm et al. (2006), only 4 pilasters were known.
}

one of the pilasters is still under discussion but resembles an Isis/Tyche of the caryatid type (Boehm et al. 2016, pp. 311). A very close parallel can be found in the decoration of the Severan basilica of Leptis Magna (Fischer 1995, pp. 139, Bruno and Bianchi 2015), where nine small pilasters represented caryatids in different positions (Floriani Squarciapino 1974; Pensabene 2006).

This type of decorative subject, such as the female personification of Roman values like the Victory, is typical of Roman architecture. The sculptural decoration of the basilica included a colossal marble statue, of which just a sandaled foot survives. This might have represented one of the emperors of the Severan dynasty or a member of the imperial family (Dell'Acqua 2021b). Taken together with this sculpture, the message conveyed by the pilasters is in line with the imperial ideology of the Severan dynasty and could be interpreted as a celebration of the imperial family by the urban elite of Ascalon (Fischer 2019).

Two heart-shaped pedestal and bases, pilasters, and capitals were set at the north-corners of the basilica, while the 


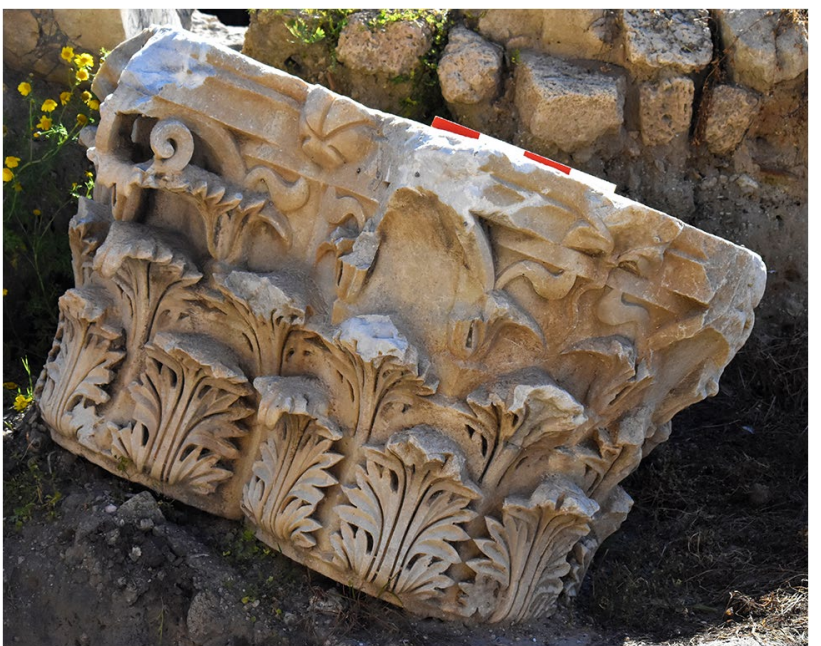

Fig. 2 The heart-shaped capital has medium grained marble, and white to slightly grey colour (PM-IL-51). The marble originates from Prokonnesos (Ph. V. Anevlavi, ÖAI/ÖAW)



Fig. 3 The column has medium grained marble, and white colour with irregular grey patches (PM-IL-18). The analysis showed that the marble of this object is coming from Karyni quarry in Lesbos Island (Ph. V. Anevlavi, ÖAI/ÖAW)

decoration of the south-corners is unknown (Fig. 2). ${ }^{8}$ The heart-shaped pilaster motif spread to other areas especially in Egypt, North Africa, and Asia Minor in Roman times. These architectural elements also appear in third century synagogues in Galilea. Pilasters in the same shape are also present in Leptis Magna in the temple of Augustus, in Augustan period Rome, in the tholoi of the market, and in the Severan period Forum Novum (Dell'Acqua 2013, pp. 1142, 1146). Further white marble Attic and Ionic bases and columns with Corinthian capitals decorated the colonnade (Figs. 3, 4, and 5). The capitals have similar forms

\footnotetext{
${ }^{8}$ On the use of heart-shaped pillars, see Dell'Acqua (2013).
}

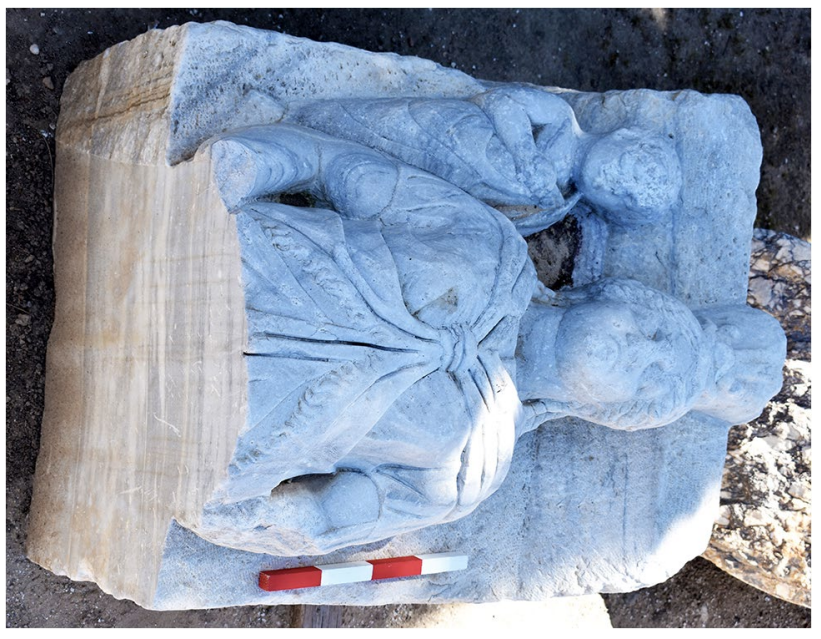

Fig. 4 The pilaster with Isis/Tyche has medium to fine grained marble, and white colour, with slightly grey banding (PM-IL-21). The pilaster is made of Prokonnesian marble (Ph. V. Anevlavi, ÖAI/ÖAW)

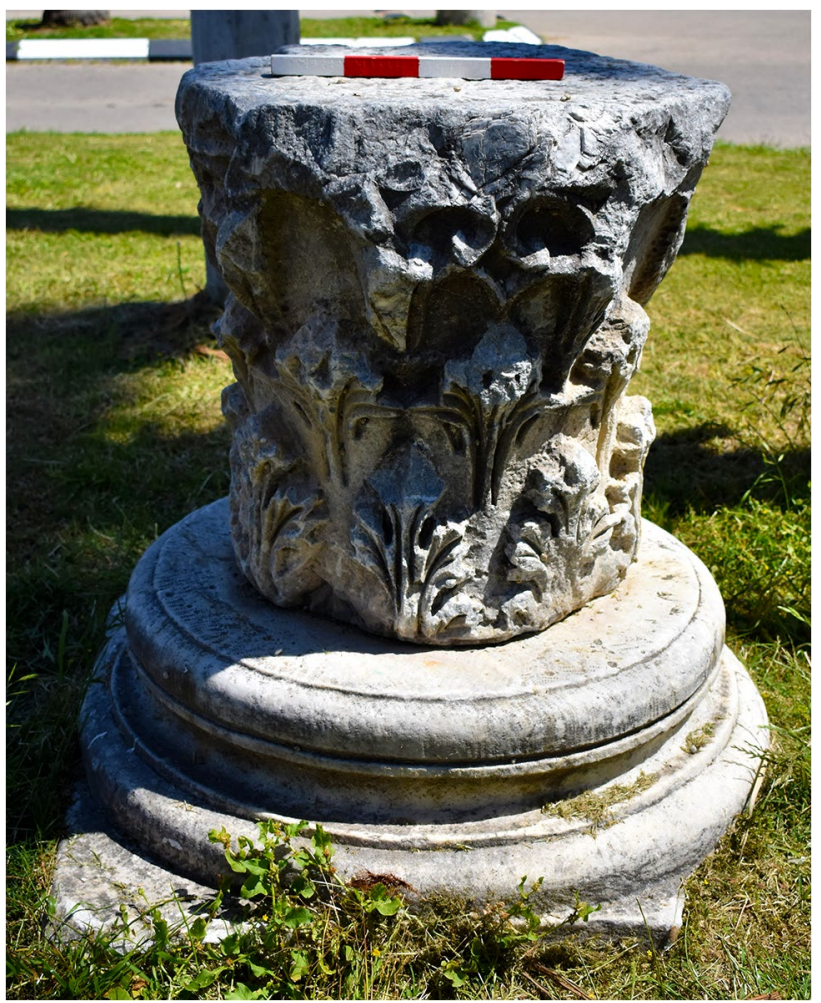

Fig. 5 The base has medium to fine grained marble, and light grey colour (PM-IL-34). The capital has medium to fine grained marble, dark grey colour, with black and white spots, and some parts with recrystallisation (PM-IL-35). The base is originated from Prokonnesian marble, while the capital is coming from Moria quarry in Lesbos (Ph. V. Anevlavi, ÖAI/ÖAW)

and dimensions as those in the basilicas of Leptis Magna, Sabratha, Alexandria, and Heraclea Pontica (Fischer 1995, 
pp. 129). Smaller capitals have been interpreted as part of the architectural decoration of the second floor of the basilica. These smaller capitals follow a tendency that started in Aphrodisias in the middle of the second century and became popular in Roman Palestine, especially in Caesarea Maritima. Similar capitals can also be found in the basilica and on the quadrifrons arch of Leptis Magna, as well as in Scythopolis, Sabratha, Thessaloniki, Side, Damascus, and Hadrumetum. ${ }^{9}$

In 1991, Pearl and Magaritz studied the provenance of marble in the Israel region with a focus on material from the archaeological sites of Scythopolis and Caesarea. Architectural elements were tested from both sites, and the results showed a wide range of sources with marble originating from Prokonnesos, Paros, Naxos, and Dokimeion (Pearl and Magaritz 1991).

In 1995, M. Fischer, A. Krug, and Z. Pearl published an interdisciplinary article on Roman Ascalon, focusing on its ancient reconstruction during the late second to early third century AD. Historical aspects were explored by considering the basilica-complex and the surrounding area in combination with archaeometrical analysis of 14 samples from the Roman centre (Fischer 1995, pp. 148-149). These 14 samples included architectural elements, the figured pilasters, and a number of sarcophagi. The methods used in this analysis included stable isotopes, XRD, and EPR analyses. The results showed that the architectural elements and two sarcophagi were made of Marmara, Prokonnesian marble. Four figured pilasters were identified as originating from different sources such as Prokonnesos, Aphrodisias, and Penteli (Fischer 1995, pp. 148-149).

\section{The sampled artefacts}

As mentioned earlier, this paper focuses only on the white marble architectural elements of the basilica. During the last campaign of the Austrian Archaeological Institute's Innovations Fund Project "Provenance Matters" (April 2019), 88 samples were collected from the site of the basilica (Ascalon Park). The 88 samples discussed in this paper are dated between the second half of the second and the third century AD. The selection includes various groups of artefacts: 36 Corinthian capitals, 11 column bases, 9 pedestals with column bases, 9 columns (and blocks with half columns), 7 fragments of figured pilasters, 5 architrave-frieze blocks, 4 floor slabs, 3 tesserae, 2 fragments of sculpture, 1 door frame, and 1 sarcophagus lid (on its secondary use)

\footnotetext{
9 After Pensabene (1977), these are semi-finished capitals of Prokonnesian marble which were completed in situ by Prokonnesian workshops.
}

(Table 1). Today, the artefacts are located in different areas of the archaeological site of the basilica: in two depot areas and in situ. All of the samples originate from the same building structure. The artefacts were selected with the assistance of Sa' ar Ganor, Rachel Bar-Natan (Israel Antiquities Authority), and Antonio Dell'Acqua (University of Tübingen), who prepared the original list of artefacts.

\section{Experimental methodology and database}

The samples were obtained in the form of small chips taken from a suitable place of an already existing ancient or modern break so that there was no loss or damage of any archaeological, art historical information, or aesthetic value.

The samples were characterised by petrographic, isotopic, chemical analyses, and trace elements analyses. More specifically, the analysis included stable isotope analysis $\left(\delta^{13} \mathrm{C}\right.$ and $\delta^{18} \mathrm{O}$ ), petrographic analysis, trace element analysis, and analysis of the fluid inclusions.

A large database of the most important quarries in antiquity supported the statistical analysis. The analysis was conducted using STATISTICA and SPSS. This interdisciplinary approach provides additional information and data filling in gaps that exist in current databases on marble provenance and analysis. The collected samples were analysed at the Department of Geosciences and Geophysics at the University of Leoben (Austria).

\section{Petrography}

Further examination using a petrographic microscope was conducted whenever the size of the corresponding sample allowed the preparation of a thin section. This additional method helped bolster results obtained by chemical analyses and statistical interpretation, especially in cases where no fresh surfaces can be examined, and weathered coating often obliterates characteristic diagnostic features. Although generally, an identification of marble provenance solely based on microscopic investigation leads to unsatisfactory results, this method provides additional data to bolster our results.

The most abundant type of marble among the architectural elements of the basilica of Ascalon is a white to greyish marble, exhibiting a light greyish weathering crust. In some cases, greyish banding can be recognised which, in connection with the medium grain size, is characteristic of marble from the Prokonnesos island. Due to the weathered surfaces, one of the challenges encountered was distinguishing the marble from the whitish to light grey limestone sourced from different quarries on the island of Lesbos as recently described and analysed by Bruno et al. (2021). 
Table 1 The sampled artefacts and their marble description. All the selected objects belong to the Basilica and nowadays are located in various findspots (Editor: V. Anevlavi, ÖAI/ÖAW)

\begin{tabular}{|c|c|c|c|c|}
\hline Project $\mathrm{Nr}$ & Artefact $\mathrm{Nr}$ & Current location & Object & Marble description \\
\hline PM-IL-001 & 1 & Office & Pedestal and base & $\begin{array}{l}\text { Fine grained, white colour, grey banding, dolo- } \\
\text { mitic layers }\end{array}$ \\
\hline PM-IL-002 & 2 & Office & Capital & Medium grained, white colour, grey banding \\
\hline PM-IL-003 & 4 & Office & Architrave frieze & Medium grained, grey colour \\
\hline PM-IL-004 & 5 & Office & Capital & Medium grained, white colour \\
\hline PM-IL-005 & 6 & Office & Capital & $\begin{array}{l}\text { Medium grained, slightly greyish colour, almost } \\
\text { no banding }\end{array}$ \\
\hline PM-IL-006 & 13 & Office & Pedestal and base & Medium grained, grey colour, irregular banding \\
\hline PM-IL-007 & 20 & Office & Frag. of sculpture & Medium grained, white colour, grey banding \\
\hline PM-IL-008 & 22 & Office & Frag. of architrave & Medium grained, white colour \\
\hline PM-IL-009 & 23 & Office & Base & $\begin{array}{l}\text { Medium grained, greyish colour, grey specks, } \\
\text { limestone }\end{array}$ \\
\hline PM-IL-010 & 25 & Office & Capital & $\begin{array}{l}\text { Medium grained, white colour, thin dark irregu- } \\
\text { lar banding }\end{array}$ \\
\hline PM-IL-011 & 26 & Office & Capital & $\begin{array}{l}\text { Fine grained, white slightly greyish colour, no } \\
\text { banding }\end{array}$ \\
\hline PM-IL-012 & 34 & Office & Frag. of sculpture & Medium grained, white colour, grey banding \\
\hline PM-IL-013 & 35 & Office & Capital & Medium grained, white colour \\
\hline PM-IL-014 & 36 & Office & Capital & Medium grained, white to light grey colour \\
\hline PM-IL-015 & 48 & Office & Pilaster with Victoria on Atlas & Medium grained, white colour \\
\hline PM-IL-016 & 52 & Office & Architrave & $\begin{array}{l}\text { Medium grained, black colour, strongly recrys- } \\
\text { tallised }\end{array}$ \\
\hline PM-IL-017 & $? 64 ?$ & Office & Column & $\begin{array}{l}\text { Medium grained, black colour, strongly recrys- } \\
\text { tallised }\end{array}$ \\
\hline PM-IL-018 & 77 & Office & Column & $\begin{array}{l}\text { Medium grained, white colour with irregular } \\
\text { grey patches }\end{array}$ \\
\hline PM-IL-019 & 202 & Office & Pilaster with Victoria & Medium grained, white-greyish colour \\
\hline PM-IL-020 & 29 & Office & Capital & $\begin{array}{l}\text { Medium grained, very white colour, homog- } \\
\text { enous }\end{array}$ \\
\hline PM-IL-021 & 203 & Office & Pilaster with Isis & $\begin{array}{l}\text { Medium to fine grained, white colour, slightly } \\
\text { grey banding }\end{array}$ \\
\hline PM-IL-022 & 204 & Office & Pilaster with Victoria & Medium grained, grey colour, irregular banding \\
\hline PM-IL-023 & 89 & Near excavation & Capital & Medium grained, white to very light grey colour \\
\hline PM-IL-024 & 90 & Near excavation & Pedestal and base & Medium grained, light grey colour \\
\hline PM-IL-025 & 91 & Near excavation & Heart-shaped pedestal and base & Medium grained, slightly greyish colour \\
\hline PM-IL-026 & 94 & Near excavation & Capital & Medium grained, slightly greyish colour \\
\hline PM-IL-027 & 96 & Near excavation & Capital & $\begin{array}{l}\text { Medium grained, greyish colour with white } \\
\text { fossil relics }\end{array}$ \\
\hline PM-IL-028 & 99 & Near excavation & Architrave, frieze & $\begin{array}{l}\text { Fine grained, with few larger crystals, slightly } \\
\text { greyish colour }\end{array}$ \\
\hline PM-IL-029 & 100 & Near excavation & Base & Medium grained, black colour \\
\hline PM-IL-030 & 103 & Near excavation & Capital & Medium grained, white slightly grey colour \\
\hline PM-IL-031 & 365 & Ascalon Afridar & Column & Medium grained, white, slightly grey colour \\
\hline PM-IL-032 & 366 & Ascalon Afridar & Pedestal and base & Medium grained, white colour, with grey bands \\
\hline PM-IL-033 & 367 & Ascalon Afridar & Capital & Medium grained, very white colour \\
\hline PM-IL-034 & 361 & Entrance & Base & Medium to fine grained, light grey colour \\
\hline PM-IL-035 & 360 & Entrance & Capital & $\begin{array}{l}\text { Medium to fine grained, dark grey colour, with } \\
\text { black and white spots, recrystallisation }\end{array}$ \\
\hline PM-IL-036 & 108 & Near excavation & Column & $\begin{array}{l}\text { White medium grained, white colour, with grey } \\
\text { patches }\end{array}$ \\
\hline PM-IL-037 & 117 & Near excavation & Architrave & $\begin{array}{l}\text { Medium grained, white colour, with grey band- } \\
\text { ing, }\end{array}$ \\
\hline
\end{tabular}


Table 1 (continued)

\begin{tabular}{|c|c|c|c|c|}
\hline Project $\mathrm{Nr}$ & Artefact $\mathrm{Nr}$ & Current location & Object & Marble description \\
\hline PM-IL-038 & 118 & Near excavation & Door frame & $\begin{array}{l}\text { Medium grained, white colour, with grey band- } \\
\text { ing }\end{array}$ \\
\hline PM-IL-039 & 143 & Near excavation & Capital & Fine grained, grey colour, homogenous \\
\hline PM-IL-040 & 150 & Near excavation & Column & $\begin{array}{l}\text { Medium grained, white colour, with grey band- } \\
\text { ing }\end{array}$ \\
\hline PM-IL-041 & 151 & Near excavation & Capital & $\begin{array}{l}\text { Fine grained, grey colour, limestone, homog- } \\
\text { enous }\end{array}$ \\
\hline PM-IL-042 & 153 & Near excavation & Block & Medium to coarse grained, white colour \\
\hline PM-IL-043 & 156 & Near excavation & Pedestal & Medium grained, grey colour, homogenous \\
\hline PM-IL-044 & 158 & Near excavation & Capital & $\begin{array}{l}\text { Medium grained, white colour, irregular grey } \\
\text { bands }\end{array}$ \\
\hline PM-IL-045 & 159 & Near excavation & Pilaster with sculpture & Medium grained, white colour, grey bands \\
\hline PM-IL-046 & 187 & Near excavation & Column & Fine grained, few larger grains, grey colour \\
\hline PM-IL-047 & 123 & Near excavation & Column & Medium grained, black colour, recrystallisation \\
\hline PM-IL-048 & 132 & Near excavation & Sarcophagus lid & Medium grained, white colour, homogenous \\
\hline PM-IL-049 & 164 & Near excavation & Capital & $\begin{array}{l}\text { Medium grained, white to slightly greyish } \\
\text { colour }\end{array}$ \\
\hline PM-IL-050 & 120 & Near excavation & Base & Medium grained, grey colour, homogenous \\
\hline PM-IL-051 & 216 & Excavation area $\mathrm{N}$ & Heart-shaped capital & Medium grained, white to slightly grey colour \\
\hline PM-IL-052 & 210 & Excavation area $\mathrm{N}$ & Pedestal and base & $\begin{array}{l}\text { Medium grained, white colour, with greyish } \\
\text { band }\end{array}$ \\
\hline PM-IL-053 & 211 & Excavation area $\mathrm{N}$ & Capital & $\begin{array}{l}\text { Medium grained, slightly greyish colour, } \\
\text { homogenous }\end{array}$ \\
\hline PM-IL-054 & 212 & Excavation area $\mathrm{N}$ & Capital & $\begin{array}{l}\text { medium grained, white colour, with black } \\
\text { specks }\end{array}$ \\
\hline PM-IL-055 & 213 & Excavation area $\mathrm{N}$ & Capital & $\begin{array}{l}\text { Medium to coarse grained, very white colour, } \\
\text { homogeneous }\end{array}$ \\
\hline PM-IL-056 & - & Excavation area $\mathrm{N}$ & Column & Medium grained, white colour, grey stripes \\
\hline PM-IL-057 & - & Excavation area $\mathrm{N}$ & Column & Medium grained, white colour \\
\hline PM-IL-058 & 227 & Excavation area $\mathrm{S}$ & Capital & Medium grained, very white colour \\
\hline PM-IL-059 & 233 & Excavation area $\mathrm{S}$ & Capital & Medium grained, white, slightly grey colour \\
\hline PM-IL-060 & 234 & Excavation area $\mathrm{S}$ & Capital & Medium grained, white colour, grey banding \\
\hline PM-IL-061 & 236 & Excavation area $\mathrm{S}$ & Pedestal and base & $\begin{array}{l}\text { Medium grained, white colour, with grey band- } \\
\text { ing }\end{array}$ \\
\hline PM-IL-062 & 239 & Excavation area $\mathrm{S}$ & Pilaster with female head (Isis/Tyche/Victoria) & Medium grained, light grey colour \\
\hline PM-IL-063 & 246 & Excavation area $\mathrm{S}$ & Pedestal and base & $\begin{array}{l}\text { Medium grained, white colour, with grey band- } \\
\text { ing }\end{array}$ \\
\hline PM-IL-064 & 253 & Excavation area $\mathrm{S}$ & Capital & $\begin{array}{l}\text { Medium grained, white colour, slightly greyish } \\
\text { at bottom part }\end{array}$ \\
\hline PM-IL-065 & 256 & Excavation area $\mathrm{S}$ & Pilaster with sculpture & Medium grained, white colour, grey banding \\
\hline PM-IL-066 & - & Excavation area $\mathrm{S}$ & Tessera & Medium grained, very white colour \\
\hline PM-IL-067 & - & Excavation area $\mathrm{S}$ & Tessera & Medium grained, black colour \\
\hline PM-IL-068 & - & Excavation area $\mathrm{S}$ & Tessera & Medium grained, white colour, grey banding \\
\hline PM-IL-069 & - & Excavation area $\mathrm{S}$ & Slabs floor & Medium grained, white colour, grey banding \\
\hline PM-IL-070 & - & Excavation area $\mathrm{S}$ & Slabs floor & Medium grained, slightly greyish colour \\
\hline PM-IL-071 & - & Excavation area $\mathrm{S}$ & Slabs floor & Medium grained, white grey colour \\
\hline PM-IL-072 & - & Excavation area $\mathrm{S}$ & Slabs floor & Medium grained, white grey colour \\
\hline PM-IL-073 & 273 & Parking & Capital & Fine grained, white colour \\
\hline PM-IL-074 & 274 & Parking & Base & Fine grained, grey colour \\
\hline PM-IL-075 & 276 & Parking & Base & Medium grained, grey colour \\
\hline PM-IL-076 & 278 & Parking & Capital & $\begin{array}{l}\text { Fine grained, grey to dark grey colour, white } \\
\text { parts }\end{array}$ \\
\hline
\end{tabular}


Table 1 (continued)

\begin{tabular}{lllll}
\hline Project Nr & Artefact Nr & Current location & Object & Marble description \\
\hline PM-IL-077 & 281 & Parking & Capital & Fine grained, white colour \\
PM-IL-078 & 281 & Parking & Base & Fine grained, grey colour \\
PM-IL-079 & 287 & Parking & Base & Medium grained, white colour \\
PM-IL-080 & 288 & Parking & Capital & Fine to medium grained, white colour \\
PM-IL-081 & 197 & Parking & Capital & Fine grained, white colour \\
PM-IL-082 & 201 & Parking & Capital & Fine grained, dark grey colour \\
PM-IL-083 & 314 & Picnic area & Capital & Fine grained, white colour, schistosity \\
PM-IL-084 & 315 & Picnic area & Base & Medium grained, white to greyish colour \\
PM-IL-085 & 324 & Theatre & Capital & Fine grained, slightly grey colour, with white \\
& & & spots \\
PM-IL-086 & 327 & Theatre & Capital & Medium grained, grey colour \\
PM-IL-087 & 327 & Theatre & Base & Medium grained, grey colour \\
PM-IL-088 & 330 & Theatre & Capital & Medium grained, white colour, dark grey bands, \\
& & & & weathering \\
\hline
\end{tabular}

Very few architectural artefacts are of dark grey to almost black marble, which can easily be recognised as marble/ limestone from the Moria quarry on the island of Lesbos.

Microscopic images of selected examples from each category are presented below.

Prokonnesian marble As mentioned above, Prokonnesian marble makes up the largest segment of investigated artefacts. Thin sections reveal the typical micro textures, which are medium grain size and a heteroblastic fabric. An example for this is sample PM-IL-40 which is a column of distinctly banded marble exhibiting the typical heteroblastic fabric of
Prokonnesian marble under the microscope (Fig. 6). Silicate admixtures and opaque accessory minerals are rare and consist of quartz, mica, and pyrite. Prokonnesian marble in general is calcitic, but it commonly shows dolomitic admixtures in highly varying degrees (Prochaska 2015). Dolomite crystals are usually small with a grain size well below $0.5 \mathrm{~mm}$. Figure 7 is a microscopic image of sample PM-IL-22 representing a pilaster relief of Nike. In this case, the dolomitic share is up to $40 \%$. Dolomite forms elongated aggregates or layers which are pronounced by a slight schistosity.

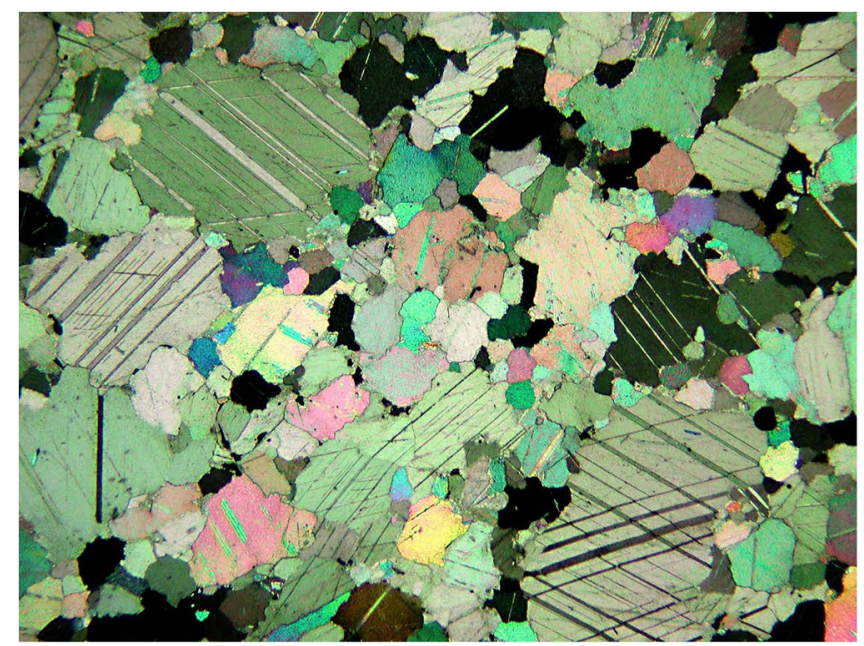

Fig. 6 Microphoto of sample PM-IL-40 with the typical heteroblastic Prokonessian texture and modestly intermeshing grain boundaries. The opaque mineral on the right-hand side of the image is pyrite (left

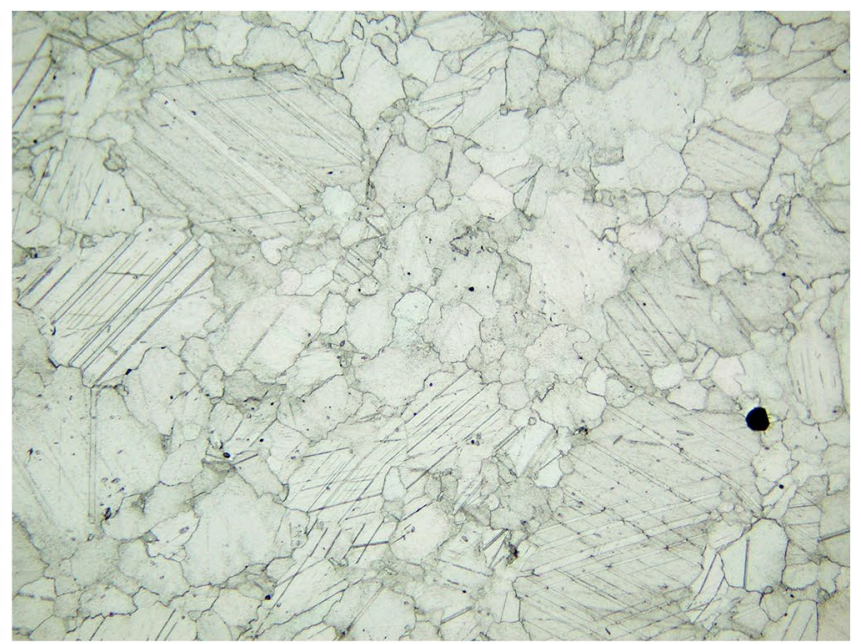

hand side: polarised light; right hand side: transmitted light; image length is $6 \mathrm{~mm})(\mathrm{Ph}$. W. Prochaska ÖAI/ÖAW) 


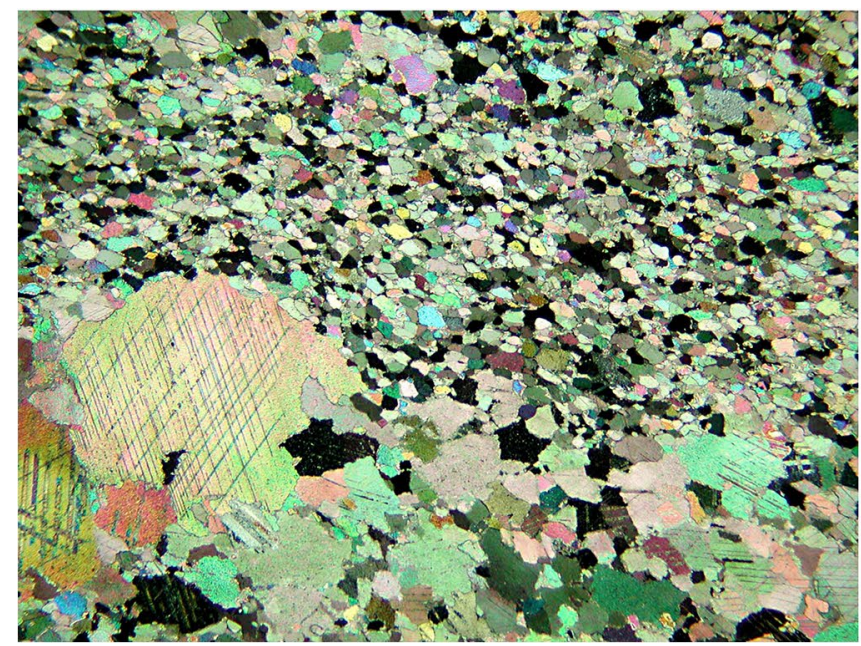

Fig. 7 Microphoto of sample PM-IL-22 with a high amount of dolomitic admixture up to approx. $40 \%$. The dolomite crystals are very fine-grained and usually very transparent. The somewhat dull appear-

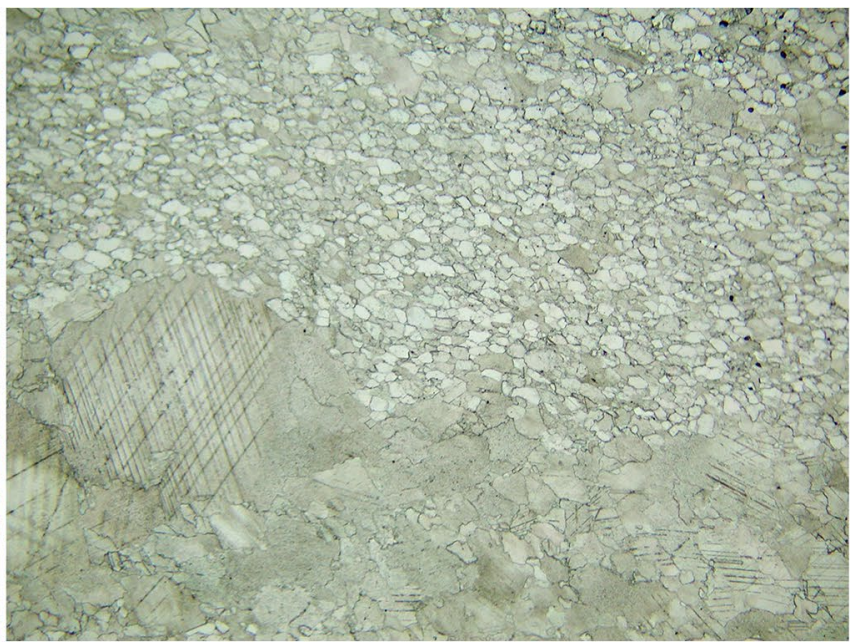

ance of the bigger calcite blasts is due to a large amount of very small fluid inclusions (left hand side: polarised light; right hand side: transmitted light; image length is $6 \mathrm{~mm})(\mathrm{Ph}$. W. Prochaska ÖAI/ÖAW)

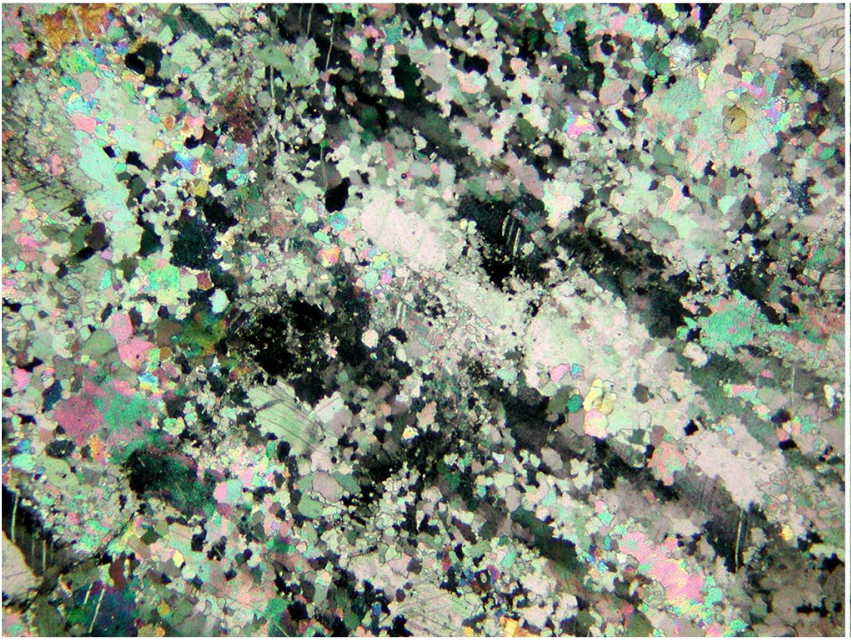

Fig. 8 Sample PM-IL-50 is a limestone with beginning recrystallisation along the fossil grain boundaries. Stylolites and sporadic dolomite crystals (darker small crystals) are ubiquitous (left hand side:

Light grey to white Lesbos marble As previously mentioned, a number of architectural elements of light grey marble occur. From a petrographic point of view, this marble is actually limestone with different degrees of beginning recrystallisation. In these cases, the differentiation of Prokonnesian marble is not easy, especially when only weathered surfaces can be examined. These types of limestone/marble prominently occur (besides the well-known black Moria marble) on the island of Lesbos. Several quarries were recently discovered, with extensively published studies making comprehensive data and analyses available (Bruno et al. 2021).

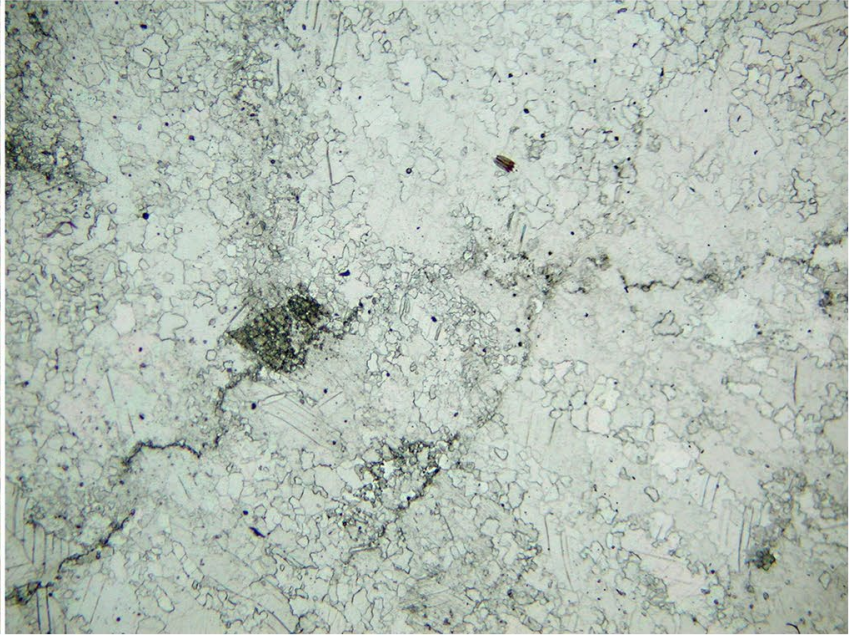

polarised light; right hand side: transmitted light; image length is 6mm) (Ph. W. Prochaska ÖAI/ÖAW)

Because of this striking resemblance with the Prokonnesian marble, a petrographic investigation was performed on all samples that could not be directly assigned. In the following paragraphs, some examples of this type of light grey Lesbos marble are presented.

The typical texture is that of a fossiliferous limestone with shell fragments showing the characteristic undulatory extinction and the decussate fabric (Fig. 8). Furthermore, pressure dissolution zigzag boundaries (stylolites) are typical. In between the fossil relics, beginning calcite recrystallisation in different intensity can be observed. As usual, this 


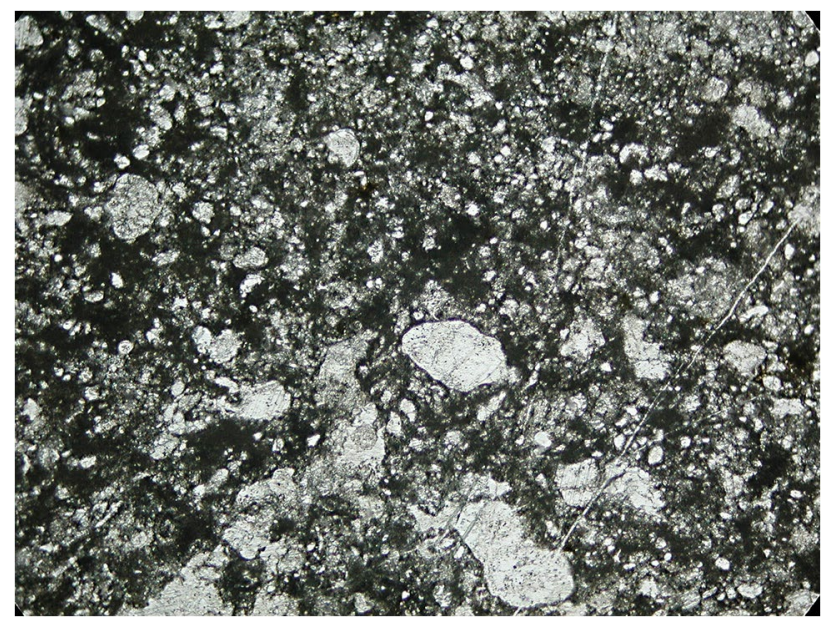

Fig. 9 Black (Moria) limestone with high amount of organic matter and with very low recrystallisation (sample PM-IL-29, polarised light; image length is in both cases $6 \mathrm{~mm})(\mathrm{Ph}$. W. Prochaska ÖAI/ ÖAW)

phenomenon is pronounced in the pure, white varieties of the limestone, in contrast to the darker types where higher contents of organic matter and silicate minerals prevent early recrystallisation (see also Prochaska et al. 2018).

The example of sample PM-IL-29 demonstrates the small-scale, patchy recrystallisation (Fig. 9). In Fig. 10, two microphotos from the same thin section are displayed showing, on the one hand, a still intact limestone with only minor recrystallisation of the fossil fragments, and on the other, an adjacent sector in the same slide with good recrystallisation and a "marble-like" texture. Petrographically, the microscopic picture of this partly recrystallised limestone is a typical palimpsest texture.

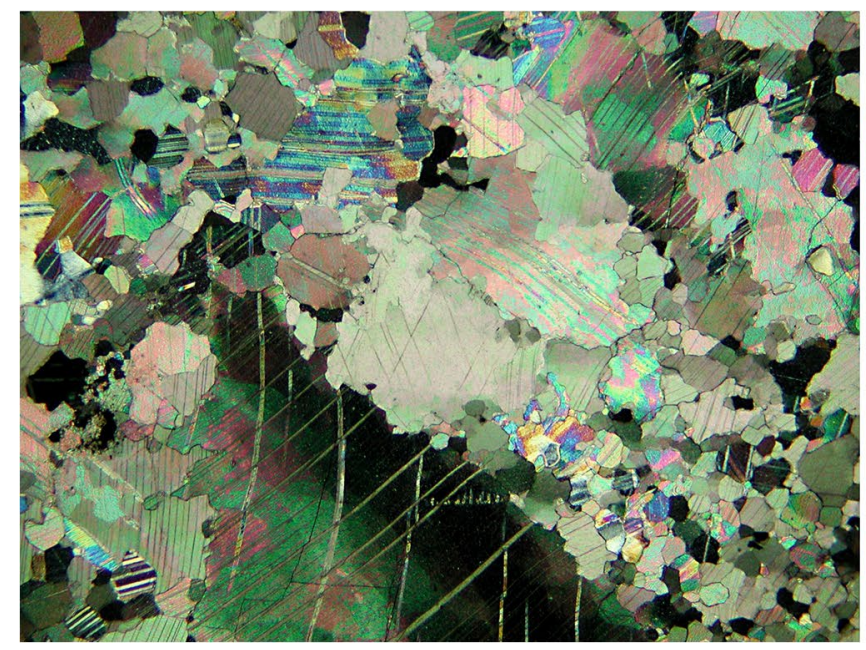

Fig. 10 Different degrees of recrystallisation on a small scale within the same sample (PM-IL-83). On the left-hand side, fossil relics still can be seen whereas on the right hand, far advanced recrystallisation
The dark grey to black Moria limestone shows a wide variety of textures according to the original sedimentary precursor rocks (Bruno et al. 2021). High amounts of organic and also silicatic impurities and low degrees of recrystallisation are common.

\section{Results}

The data for the analysed marble objects in the present work is provided under "Supplementary Online Material". The samples were divided into different groups according to their characteristics. The presented diagrams show the comparison of the unknown artefacts with ancient marble sources. The artefacts are separated in two main groups based on the material: the first group is the marble group, while the second is the limestone-marble group. The results of each group are depicted in 4 diagrams (two stable isotope diagrams and two multivariate diagrams).

The first group was compared with the quarries of Penteli, Dokimeion, Thasos, Prokonnesos, and Prokonnesos III (subset of Prokonnesos, see Prochaska and Attanasio 2021). In total, 66 sample groups such as pedestal and column bases, columns, bases, sculptures, pilasters, capitals, other architectural elements, and tesserae were compared. The stable isotope results showed that most of the artefacts fit the Prokonnesian ellipse (Fig. 11).

Figure 12 shows the multivariate diagram of this group, making it evident that a clearer discrimination of the different quarry locations can be achieved on this basis. The variables used for the statistical analysis are the $\delta^{18} \mathrm{O}, \delta^{13} \mathrm{C}$,

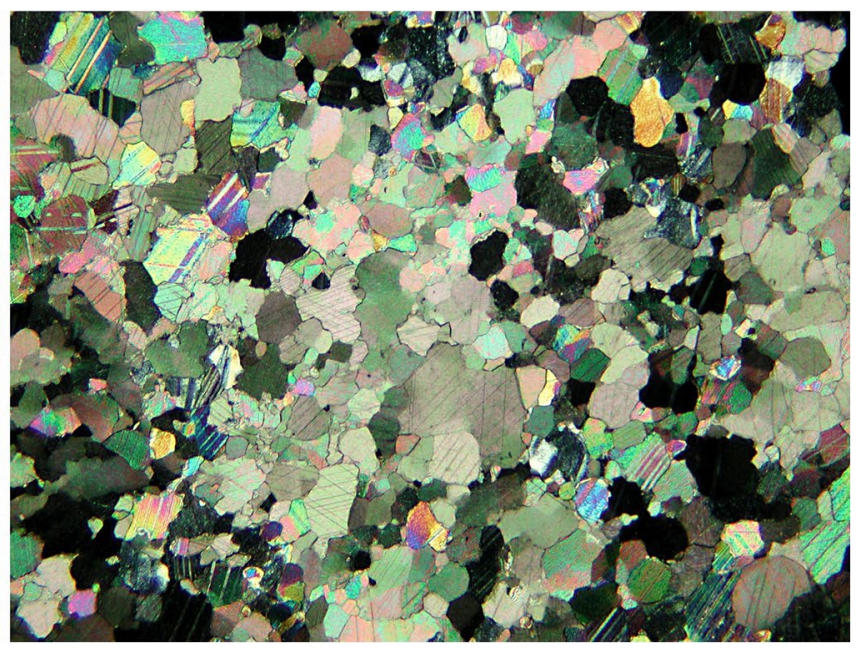

took place (polarised light; image length is in both cases $6 \mathrm{~mm})(\mathrm{Ph}$. W. Prochaska ÖAI/ÖAW) 


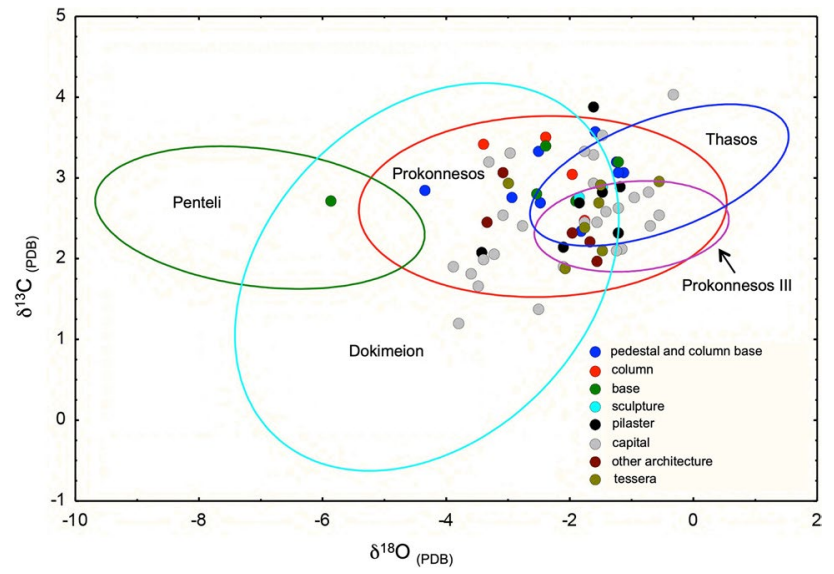

Fig. 11 Isotope diagram of the marble artefacts of the Basilica. (Editor: W. Prochaska, ÖAI/ÖAW)

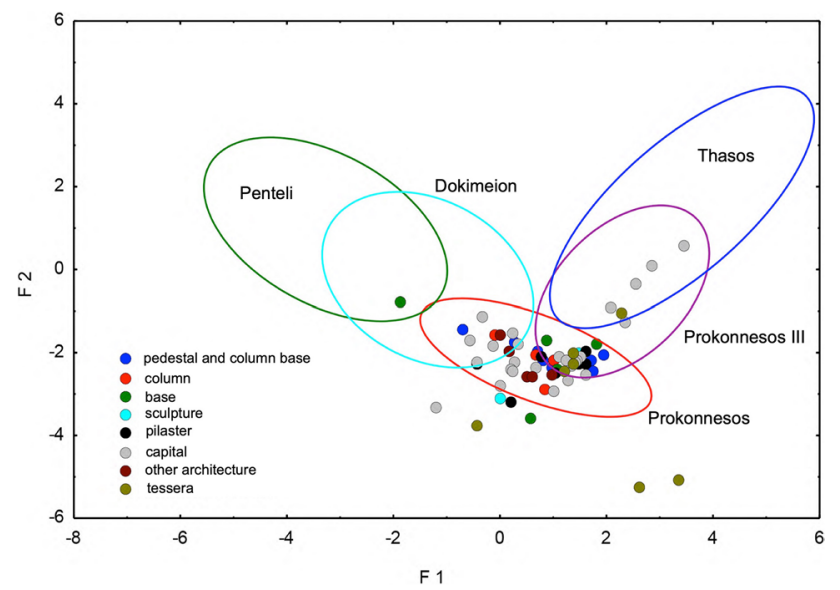

Fig. 12 Multivariate diagram of the marble artefacts of the Basilica. Variables used: $\delta 180, \delta 13 \mathrm{C}, \mathrm{Fe}, \mathrm{Mn}, \mathrm{Sr}, \mathrm{Cr}, \mathrm{V}, \mathrm{Y}, \mathrm{Cd}, \mathrm{Ba}, \mathrm{La}, \mathrm{Ce}, \mathrm{Pr}$, $\mathrm{Yb}$, and U (Editor: W. Prochaska, ÖAI/ÖAW)

Fe, Mn, Sr, Cr, V, Y, Cd, Ba, La, Ce, Pr, Yb, and U. The majority of the artefacts originated from Prokonnesos, while a smaller group comes from Prokonnesos III.

The artefacts of the second group were compared with limestone-marble sources located on Lesbos Island. The locations were Moria, Karyni, Alyfantas, Ippios, and Tarti (details and data reported in Bruno et al. 2021). The dashed line shows the Prokonnesian ellipse. However, the geologic and/or petrographic characteristics do not fit with the Prokonnesian quarries. The majority of the artefacts are located in the Karyni ellipse. Fifteen artefacts belong to the second group and are separated in different categories such as architraves, bases, columns, and capitals (Fig. 13).

The multivariate diagram of the second group shows the sample plot in the Moria and Karyni field of Lesbos,

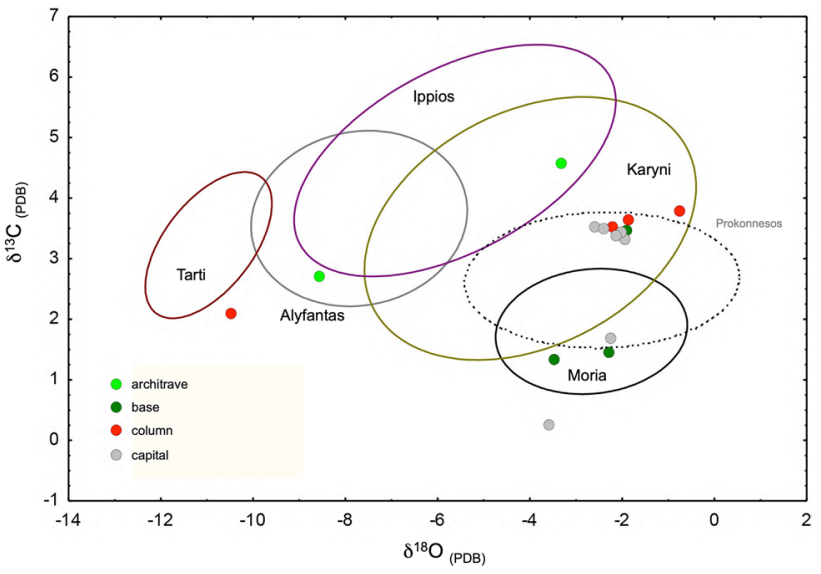

Fig. 13 Isotope diagram of the limestone artefacts of the Basilica (Editor: W. Prochaska, ÖAI/ÖAW)

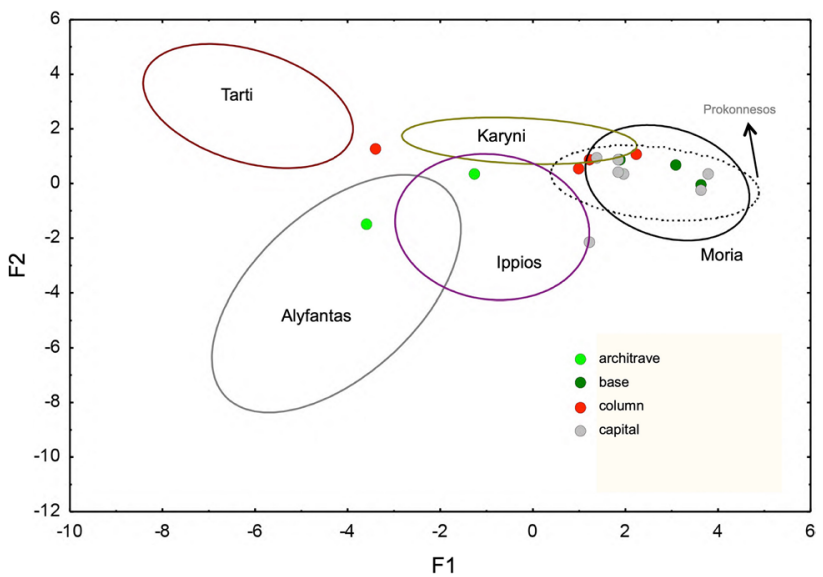

Fig. 14 Multivariate diagram of the limestone artefacts of the Basilica. Variables used: $\delta 18 \mathrm{O}, \delta 13 \mathrm{C}, \mathrm{Fe}, \mathrm{Mn}, \mathrm{Sr}, \mathrm{Cr}, \mathrm{V}, \mathrm{Y}, \mathrm{Cd}, \mathrm{Ba}, \mathrm{La}$, $\mathrm{Ce}, \mathrm{Pr}, \mathrm{Yb}$, and U (Editor: W. Prochaska, ÖAI/ÖAW)

although some artefacts could have originated from Alyfantas and Ippios (Fig. 14). The results of the individual samples are presented in Tables 2 and 3.

\section{Discussion}

Roman Palestine was mainly an importer of rough or semifinished marble artefacts, which included architectural elements, sculptures, and sarcophagi. Together with the harbour city Caesarea Maritima, Ascalon represented an important centre in the Mediterranean trade network of Roman Palestine: imported building materials reached the city directly by sea and these were used for decorating the monuments of the city. 
Table 2 The calculated statistical parameters of the investigated marble samples (Editor: W. Prochaska, ÖAI/ ÖAW)

\begin{tabular}{|c|c|c|c|c|c|c|}
\hline Sample & $\begin{array}{l}\text { Distance } \\
\text { 1. Choice }\end{array}$ & Abs. prob. & Rel. prob. & Provenance & $\begin{array}{l}\text { Rel. prob. } \\
\text { 2. Choice }\end{array}$ & Provenance \\
\hline PM-IL-1 & 2.7 & 60.3 & 99.8 & Prokonnesos & 0.1 & Thasos \\
\hline PM-IL-6 & 1.1 & 89.2 & 99.7 & Prokonnesos & 0.3 & Prokonnesos III \\
\hline PM-IL-24 & 1.5 & 82.2 & 97.6 & Prokonnesos & 2.0 & Prokonnesos III \\
\hline PM-IL-25 & 1.6 & 81.0 & 99.0 & Prokonnesos & 1.0 & Prokonnesos III \\
\hline PM-IL-32 & 0.7 & 95.2 & 99.9 & Prokonnesos & 0.1 & Prokonnesos III \\
\hline PM-IL-43 & 0.9 & 92.6 & 98.6 & Prokonnesos & 1.3 & Prokonnesos III \\
\hline PM-IL-52 & 1.3 & 86.1 & 99.8 & Prokonnesos & 0.2 & Prokonnesos III \\
\hline PM-IL-61 & 0.4 & 97.7 & 99.8 & Prokonnesos & 0.2 & Dokimeion \\
\hline PM-IL-63 & 2.8 & 58.6 & 98.0 & Prokonnesos & 1.4 & Dokimeion \\
\hline PM-IL-31 & 1.3 & 86.0 & 99.9 & Prokonnesos & 0.0 & Prokonnesos III \\
\hline PM-IL-40 & 2.9 & 56.8 & 99.8 & Prokonnesos & 0.1 & Prokonnesos III \\
\hline PM-IL-56 & 1.1 & 88.7 & 100.0 & Prokonnesos & 0.0 & Dokimeion \\
\hline PM-IL-57 & 0.4 & 97.8 & 99.6 & Prokonnesos & 0.3 & Prokonnesos III \\
\hline PM-IL-34 & 0.8 & 93.4 & 99.8 & Prokonnesos & 0.2 & Prokonnesos III \\
\hline PM-IL-75 & 6.5 & 16.2 & 79.9 & Penteli & 17.2 & Prokonnesos \\
\hline PM-IL-79 & 0.4 & 97.9 & 99.9 & Prokonnesos & 0.0 & Dokimeion \\
\hline PM-IL-84 & 1.5 & 82.4 & 99.1 & Prokonnesos & 0.7 & Prokonnesos III \\
\hline PM-IL-74 & 5.3 & 25.0 & 100.0 & Prokonnesos & 0.0 & Dokimeion \\
\hline PM-IL-7 & 2.3 & 68.5 & 100.0 & Prokonnesos & 0.0 & Dokimeion \\
\hline PM-IL-12 & 0.8 & 93.0 & 99.8 & Prokonnesos & 0.1 & Prokonnesos III \\
\hline PM-IL-15 & 1.2 & 88.0 & 98.2 & Prokonnesos & 1.8 & Prokonnesos III \\
\hline PM-IL-19 & 2.5 & 63.9 & 100.0 & Prokonnesos & 0.0 & Dokimeion \\
\hline PM-IL-21 & 0.7 & 95.4 & 99.1 & Prokonnesos & 0.7 & Dokimeion \\
\hline PM-IL-22 & 1.2 & 87.2 & 99.2 & Prokonnesos & 0.8 & Dokimeion \\
\hline PM-IL-45 & 0.9 & 92.3 & 99.9 & Prokonnesos & 0.1 & Prokonnesos III \\
\hline PM-IL-62 & 5.1 & 27.1 & 100.0 & Prokonnesos & 0.0 & Thasos \\
\hline PM-IL-65 & 0.3 & 98.8 & 99.7 & Prokonnesos & 0.2 & Prokonnesos III \\
\hline PM-IL-2 & 0.6 & 96.4 & 99.7 & Prokonnesos & 0.2 & Prokonnesos III \\
\hline PM-IL-4 & 1.3 & 85.8 & 99.8 & Prokonnesos & 0.2 & Prokonnesos III \\
\hline PM-IL-5 & 0.9 & 92.2 & 96.5 & Prokonnesos III & 3.1 & Prokonnesos \\
\hline PM-IL-10 & 0.6 & 95.5 & 98.5 & Prokonnesos & 1.4 & Prokonnesos III \\
\hline PM-IL-11 & 2.5 & 64.2 & 79.0 & Prokonnesos & 20.8 & Dokimeion \\
\hline PM-IL-14 & 1.4 & 83.0 & 97.8 & Prokonnesos & 2.0 & Prokonnesos III \\
\hline PM-IL-20 & 1.2 & 86.5 & 99.6 & Prokonnesos & 0.3 & Prokonnesos III \\
\hline PM-IL-23 & 0.7 & 94.4 & 98.8 & Prokonnesos III & 1.2 & Thasos \\
\hline PM-IL-30 & 1.6 & 80.3 & 99.6 & Prokonnesos & 0.4 & Prokonnesos III \\
\hline PM-IL-33 & 0.3 & 91.1 & 99.2 & Prokonnesos III & 0.7 & Thasos \\
\hline PM-IL-44 & 0.8 & 92.9 & 98.3 & Prokonnesos & 1.6 & Dokimeion \\
\hline PM-IL-49 & 1.2 & 87.7 & 98.6 & Prokonnesos & 0.7 & Dokimeion \\
\hline PM-IL-51 & 1.2 & 86.8 & 99.8 & Prokonnesos & 0.1 & Dokimeion \\
\hline PM-IL-53 & 0.2 & 99.5 & 99.8 & Prokonnesos & 0.2 & Dokimeion \\
\hline PM-IL-54 & 1.7 & 79.0 & 100.0 & Prokonnesos & 0.0 & Dokimeion \\
\hline PM-IL-58 & 0.6 & 95.3 & 99.8 & Prokonnesos & 0.2 & Prokonnesos III \\
\hline PM-IL-59 & 1.9 & 74.7 & 95.2 & Prokonnesos & 4.6 & Prokonnesos III \\
\hline PM-IL-60 & 0.6 & 96.0 & 99.2 & Prokonnesos III & 0.7 & Prokonnesos \\
\hline PM-IL-64 & 0.7 & 95.1 & 99.4 & Prokonnesos & 0.5 & Prokonnesos III \\
\hline PM-IL-76 & 2.2 & 69.8 & 99.0 & Prokonnesos & 1.0 & Dokimeion \\
\hline PM-IL-88 & 0.3 & 98.4 & 99.7 & Prokonnesos & 0.2 & Dokimeion \\
\hline PM-IL-13 & 3.9 & 41.7 & 78.2 & Thasos & 21.7 & Prokonnesos III \\
\hline PM-IL-73 & 3.7 & 44.9 & 88.7 & Prokonnesos & 11.2 & Dokimeion \\
\hline
\end{tabular}


Table 2 (continued)

\begin{tabular}{lllllll}
\hline Sample & $\begin{array}{l}\text { Distance } \\
\text { 1. Choice }\end{array}$ & Abs. prob. & Rel. prob. & Provenance & $\begin{array}{l}\text { Rel. prob. } \\
\text { 2. Choice }\end{array}$ & Provenance \\
\hline PM-IL-77 & 3.2 & 52.0 & 80.4 & Prokonnesos & 19.6 & Dokimeion \\
PM-IL-81 & 7.5 & 11.1 & 88.2 & Prokonnesos & 11.8 & Dokimeion \\
PM-IL-83 & 2.0 & 73.3 & 92.6 & Dokimeion & 7.2 & Prokonnesos \\
PM-IL-38 & 0.7 & 94.1 & 99.9 & Prokonnesos & 0.1 & Dokimeion \\
PM-IL-28 & 1.0 & 90.3 & 99.5 & Prokonnesos & 0.4 & Prokonnesos III \\
PM-IL-42 & 0.7 & 94.3 & 99.0 & Prokonnesos & 0.9 & Dokimeion \\
PM-IL-8 & 0.9 & 92.0 & 99.6 & Prokonnesos & 0.2 & Dokimeion \\
PM-IL-37 & 0.8 & 92.8 & 99.6 & Prokonnesos & 0.4 & Prokonnesos III \\
PM-IL-26 & 16.2 & 0.3 & 99.6 & Prokonnesos & 0.4 & Prokonnesos III \\
PM-IL-68 & 13.8 & 0.8 & 99.9 & Prokonnesos & 0.1 & Prokonnesos III \\
PM-IL-48 & 0.7 & 94.9 & 98.5 & Prokonnesos III & 1.3 & Prokonnesos \\
PM-IL-69 & 0.5 & 97.3 & 99.9 & Prokonnesos & 0.1 & Prokonnesos III \\
PM-IL-70 & 4.5 & 34.2 & 99.9 & Prokonnesos & 0.1 & Dokimeion? \\
PM-IL-71 & 1.3 & 85.4 & 99.3 & Prokonnesos & 0.3 & Prokonnesos III \\
PM-IL-72 & 0.6 & 95.9 & 99.3 & Prokonnesos & 0.6 & Prokonnesos III \\
\hline
\end{tabular}

Distance: Distance of the sample under consideration from the centre of the ellipse that represents the quarry probability field. The central point of the ellipse expresses the average and hence most characteristic values of a quarry. The closer a point is to the centre of an ellipse, the more likely is the provenance from that marble site. Relative (posterior) probability: Probability of the sample to belong to some group within the assumption that it originates in any case from one of the groups in the selection. The threshold is $60 \%$. Low values indicate that the sample's assignment is in doubt between two or more groups. Absolute (typical) probability: This is a distance dependent parameter measuring the absolute probability that the sample belongs to the chosen group or, in other words, is a typical representative of the group properties. The threshold is $10 \%$, corresponding to samples on the edge of the $90 \%$ probability ellipse. Low values indicate anomalous samples (outliers) or samples possibly not belonging to any group in the selection

As it has been pointed out, previous research on Ascalon has shown that marble from the island of Prokonnesos was extensively used here for the architectural decoration (Ward Perkins 1951; Ward Perkins 1993; Russell 2013). ${ }^{10}$ The results of the marble analysis confirm that the Marmara island (Marmara Sea) was the main marble supplier between the second half of the second and the third century, used for the monumentalisation of Ascalon. The Severan phase of the Ascalon basilica included 62 investigated artefacts that were made of this marble, accounting for $70.5 \%$ of the sampled objects. These included a range of architectural decorative elements such as floor slabs, pedestals, bases, columns, pilasters, architraves, and capitals. Prokonnesian marble was also present in reused objects like the sarcophagus lid (PM-IL-048) and in the floor tesserae of the post-Severan phase of the basilica. The use of Prokonnesian marble in Roman Palestine can also be seen in Beth Shean and its theatre (Romano and Fischer 2009). In general, Prokonnesos is one of the most important marble sources of antiquity. Since the 70s, Nusin Asgari has published various articles

\footnotetext{
10 On the use of Prokonnesian marble also for sculpture, see Musso et al. (2016); Musso et al. (2018).
}

all related to Prokonnesos and its quarries, architecture, unfished objects, workshops, trade etc. (Asgari 1977, 1978, 1992, 1990, Asgari and Matthews 1995, Asgari and DrewBear 2002). Archaeometrical studies of Attanasio (2003) and Attanasio et al. (2006) focused on the fingerprinting of Prokonnesian marble. Countless publications with archaeological and archaeometrical application have proven the use of Prokonnesian marble all over the Mediterranean, with great examples present in buildings in Rome (Baths of Caracalla), Leptis Magna, Ephesus etc. (e.g. Attanasio et al. 2008). Evidence of the supra-regional use is also present in several shipwrecks and their cargo. A famous example is the Marzamemi shipwreck in Sicily dated in the early Byzantine period (500 AD), which was loaded with Prokonnesian material (Kokkorou-Alevra et al. 2006).

Monumental building activities took place in the Severan age in many centres of the empire, but were particularly intensive in North Africa and the Levant. The consequence was the opening of new marble sources and the full exploitation of the existing quarries. The monumentalisation of Leptis Magna, birthplace of the emperor Septimius Severus, with the new planning and building of the Forum-TempleBasilica complex is an exemplary case of massive building activities financed by the imperial house (Bianchi 2009; 
Table 3 The calculated statistical parameters of the investigated limestone samples (Editor: W. Prochaska, ÖAI/ ÖAW)

\begin{tabular}{lllllll}
\hline Sample & $\begin{array}{l}\text { Distance } \\
\text { 1. Choice }\end{array}$ & Abs. prob. & Rel. prob. & Provenance & $\begin{array}{l}\text { Rel. prob. } \\
\text { 2. Choice }\end{array}$ & Provenance \\
\hline PM-IL-03 & 3.4 & 49.1 & 100.0 & Karyni, Lesbos & 0.00 & Ippios \\
PM-IL-16 & 5.2 & 26.5 & 100.0 & Alyfantas, Lesbos & 0.00 & Tarti \\
PM-IL-09 & 1.1 & 88.3 & 100.0 & Moria, Lesbos & 0.00 & Karyni \\
PM-IL-29 & 0.6 & 95.5 & 100.0 & Moria, Lesbos & 0.00 & Karyni \\
PM-IL-50 & 6.4 & 17.0 & 72.0 & Karyni, Lesbos & 28.0 & Moria \\
PM-IL-17 & 7.3 & 11.8 & 100.0 & Tarti, Lesbos & 0.00 & Alyfantas \\
PM-IL-18 & 3.9 & 42.1 & 98.6 & Karyni, Lesbos & 1.4 & Moria \\
PM-IL-36 & 4.7 & 31.7 & 95.4 & Karyni, Lesbos & 4.6 & Moria \\
PM-IL-46 & 8.4 & 7.5 & 70.6 & Karyni, Lesbos & 29.4 & Moria \\
PM-IL-27 & 4.7 & 31.3 & 88.1 & Moria, Lesbos & 11.9 & Karyni \\
PM-IL-35 & 1.4 & 84.4 & 100.0 & Moria, Lesbos & 0.00 & Karyni \\
PM-IL-39 & 5.9 & 20.4 & 83.5 & Karyni, Lesbos & 16.5 & Moria \\
PM-IL-41 & 4.1 & 38.5 & 94.3 & Karyni, Lesbos & 5.7 & Moria \\
PM-IL-78 & 2.8 & 59.0 & 100.0 & Moria, Lesbos & 0.00 & Karyni \\
PM-IL-85 & 6.4 & 16.9 & 62.0 & Moria, Lesbos & 38.0 & Karyni \\
PM-IL-86 & 10.3 & 3.5 & 95.0 & Moria, Lesbos & 5.0 & Karyni \\
\hline
\end{tabular}

Distance: Distance of the sample under consideration from the centre of the ellipse that represents the quarry probability field. The central point of the ellipse expresses the average and hence most characteristic values of a quarry. The closer a point is to the centre of an ellipse, the more likely is the provenance from that marble site. Relative (posterior) probability: Probability of the sample to belong to some group within the assumption that it originates in any case from one of the groups in the selection. The threshold is $60 \%$. Low values indicate that the sample's assignment is in doubt between two or more groups. Absolute (typical) probability: This is a distance dependent parameter measuring the absolute probability that the sample belongs to the chosen group or, in other words, is a typical representative of the group properties. The threshold is $10 \%$, corresponding to samples on the edge of the $90 \%$ probability ellipse. Low values indicate anomalous samples (outliers) or samples possibly not belonging to any group in the selection
Bianchi et al. 2011, pp. 329). ${ }^{11}$ On the other hand, no particular link exists between the imperial family and the city of Ascalon and there is no evidence of an imperial visit to the city or imperial evergetism towards this community. Therefore, it can be argued that the commissioners of the building programme in Ascalon most probably were the urban elites who wanted to pay homage to the emperor with monumental and luxurious buildings in the city centre (see also Fischer 2019, p. 30; Dell'Acqua 2021a). Nonetheless, the restoration programme pursued in Ascalon seems to have many common elements with the cities of Tripolitania.

The similarities between the two Severan basilicas in Ascalon and Leptis Magna are striking and not limited to stylistic aspects. The pilasters of the basilica of Ascalon not only show decorative similarities with the ones in Leptis Magna, but they were also all produced in Prokonnesos and were probably decorated by Prokonnesian artisans, perhaps from the Nicomedian and Aphrodisian schools (Ward Perkins 1993, pp. 98-103; Pensabene 2006). The exceptional similarity of the objects had led M. Fischer to put forward

\footnotetext{
11 On the Basilica of Leptis Magna, see Floriani Squarciapino (1966), pp. 105-110; Floriani Squarciapino (1974).
}

the hypothesis of a common origin of the pilasters of the two basilicas, although he assumed that the materials of the Ascalon pilasters originated from different marble sources (Fischer 1995). Our analysis has demonstrated that all the four figured pilasters of the basilica Ascalon are of Prokonnesian marble, exactly like the ones in Leptis Magna. According to analysis by Walda and Walker, the ones from Leptis Magna were of Prokonnesian and Thasian marble (Walda and Walker 1988, pp. 55-59), but Ward Perkins has recognised them all as coming from Prokonnesos. ${ }^{12}$ In contrast to the situation in Leptis Magna, only one piece from the basilica of Ascalon is made of Thasian marble (capital, PM-IL-13).

Similarities between the Ascalon and Leptis Magna case studies can be found in other materials such as the Troad granite. Columns made from material obtained from this specific source can be seen in the theatre of Leptis Magna, the basilica, and the decumanus (Pensabene et al. 2015).

Research conducted by Bianchi et al. in 2011 at Leptis Magna on its marmorisation showed an extended use of

\footnotetext{
12 On the marbles used in the Severan buildings of Leptis Magna, see Ward Perkins (1993), pp. 88-90; Bruno and Bianchi (2015).
} 
Prokonnesian and Pentelic marble for architectural elements. According to the study, roughly shaped elements were brought to Leptis Magna where about 300 Pentelic column bases and capitals coming from different sources around the mountain of Pentelikon can be identified (Bianchi et al. 2015, pp. 33).

Marble from different quarries on the island of Lesbos has been identified in 15 of the analysed samples. This was used for bases, columns, architraves, and capitals. The same stone has been recently identified by F. Bianchi and M. Bruno in various architectural elements of the Severan complex of Leptis Magna (Bianchi et al. 2020, in press).

Recent investigations on the island of Mytilini (Lesbos) discovered extended extraction of material in several areas across the island. Lesbos was known from antiquity for the marmor Lesbium, whose quarries are located near the modern village of Moria. The marmor Lesbium or bigio lumachellato was used mostly for the production of architectural elements. The material extracted from Moria has a characteristic texture and colour. It has a dark grey to black colour and contains shells (megalodonts) which makes the marble special and diagnostic (Leka and Zachos 2015, pp. 202). Smaller quarries in central and eastern part of Lesbos can be found in Alyfanta, Tarti, Karyni, and Ippios, with Karyni being the second largest quarry on the island after Moria (Attanasio et al. in press). ${ }^{13}$ Lastly, Karyni marble is a white to light grey colour.

Provenance studies have demonstrated that the use of the Lesbian marble spread across the Mediterranean world since Hadrianic times. Examples can be found in Asia Minor (Cramer 2004), North Africa, Italy, Rome, and Ostia (Attanasio et al. in press). A study by Attanasio et al. (2018) completed the fingerprinting of these locations with the use of different methods (EPR, stable isotopes, trace element analysis), adding important information on the general marble database. In continuing the geological characterisation of these quarries, further archaeometrical analysis showed that more than 200 elements of architecture in Leptis Magna originated from Lesbos quarries, highlighting the importance of this source as a production centre in addition to the acquisition of Prokonnesian marble (Attanasio et al. in press). Considering the visual similarity of the two types of stone, this interpretation makes sense, although for an ancient observer, the visual differences might have been imperceptible.

Parallel to the study of Lesbos quarries, in 2018, the Bianchi et al. research group (complete paper 2022, in press) re-visited Leptis Magna and re-sampled many unidentified

\footnotetext{
13 For a detailed description of the quarries in Moria, Alyfanta, Tarti, Karyni, and Ippios, see Bianchi et al. (2020), 21-22 (Moria), 22-24 (Alyfanta), 25-26 (Tarti), 27-29 (Karyni), 29-30 (Ippio).
}

artefacts. These groups can be found not only at the Severan complex, but in other buildings such as the Hadrianic Bath, the Eastern temple, the basilica on the old Forum, the Theatre, the Macellum, the Serapeum, and the temple on the Decumanus Maximus (Bianchi et al. 2020, pp. 36-49; Bianchi et al. in press). The material was marked as white to light grey, or dark grey colour, with indefinable grain size. The provenance analysis of the artefacts showed that these pieces originated from Karyni quarry in central Lesbos, but also from the Moria quarries (Bianchi et al. in press).

The use of Lesbos marble for architectural elements like bases and capitals has been demonstrated by F. Bianchi and her colleagues to be widespread in many centres of North Africa and Asia Minor (Bianchi et al. 2020, pp. 65-68). Its employment also in the Severan basilica of Ascalon strengthens the hypothesis that the quarries on Lesbos island, even if smaller in scale than those on Prokonnesos, supplied the need for raw materials used in decorating monumental buildings on the coast of the Eastern Mediterranean imperial cities.

Roman Palestine was peripheral area that absorbed marble art without any serious attempts to create its own marble-based art. This study highlights the role of Prokonnesos as the main supplier of raw building material for the basilica of Ascalon, and the importance of Prokonnesian marble in other places in Roman Palestine and North Africa. In conclusion, the presence of marble from Lesbian quarries at sites such as Ascalon and Leptis Magna should help us reconsider previous and future studies and analyses of marble artefacts and sources.

Supplementary Information The online version contains supplementary material available at https://doi.org/10.1007/s12520-022-01518-1.

Acknowledgements We would like to thank the Israeli Antiquity Authorities for the permission to perform this investigation. The comments of Dr. Antonio Antonio Dell'Acqua are gratefully acknowledged. The comments of two anonymous reviewers are very much appreciated. We would like to thank Paula Gheorghiade, Research Associate at the Archaeology Centre, University of Toronto, for proofreading and editing the English text.

Data availability All relevant data are within the manuscript. All archaeological samples are stored in the archaeological depot of the Austrian Archaeological Institute (Vienna) and are available for scientific re-evaluation on request.

Author contribution All authors contributed to the study conception and design. Material sampling and preparation, data collection, and analysis were performed by Walter Prochaska, Vasiliki Anevlavi, and Chiara Cenati. All authors read and approved the final manuscript.

Funding Open access funding provided by Österreichische Akademie der Wissenschaften. This study was funded by the Austrian Academy of Sciences, Innovation Fund: "Provenance Matters" A multi-proxy Approach for the Determination of White Marbles in the Roman East (Project No ÖAW4009). 


\section{Declarations}

Conflict of interest The authors declare no competing interests.

Open Access This article is licensed under a Creative Commons Attribution 4.0 International License, which permits use, sharing, adaptation, distribution and reproduction in any medium or format, as long as you give appropriate credit to the original author(s) and the source, provide a link to the Creative Commons licence, and indicate if changes were made. The images or other third party material in this article are included in the article's Creative Commons licence, unless indicated otherwise in a credit line to the material. If material is not included in the article's Creative Commons licence and your intended use is not permitted by statutory regulation or exceeds the permitted use, you will need to obtain permission directly from the copyright holder. To view a copy of this licence, visit http://creativecommons.org/licenses/by/4.0/.

\section{References}

Asgari N (1977) Die halbfabrikate kleinasitischen girlandensarkophage und ihre herkunft. Archäologischer Anzeiger, pp $329-80$

Asgari N (1978) Roman and early Byzantine marble quarries of Proconnesos. In Akurgal E (ed) Proceedings of X international congress of classical archaeology, vols 1-3, Ankara.

Asgari N (1990) Objects de marbre finis, semi-finis et inachevés du Proconnèse. In: Waelkens M (ed) Pierre éternelle du Nil au Rhin. Carrières et fabrication, Brussels, pp 106-126

Asgari N (1992) Observation of two types of quarry items form Proconnesos: column shafts, and column bases. Archaeologica Lovaniensia, Monograph 4, Leuven

Asgari N and Drew-Bear T (2002) The quarry inscriptions of Proconnesos. In Schvoerer M (ed) Archéomatériaux: marbres et autres roches, Bordeaux, 1-19

Asgari N, Matthews KJ (1995) The stable isotope analysis of marble from Proconnesos. In: Maniatis Y, Herz, Bassiakos Y (eds) . The study of marble and other stones used in the antiquity, London, pp 123-129

Attanasio D (2003) Ancient white marbles, analysis and identification by paramagnetic resonance spectroscopy, Rome

Attanasio D, Brilli M, Ogle N, (2006) The isotopic signature of classical marbles, Rome

Attanasio D, Brilli M, Bruno M (2008) The properties and identification of marble from Proconnesos (Marmara island, Turkey): a new database including isotopic, EPR and petrographic data. Archaeometry 50(5):747-774

Attanasio D, Prochaska W, Bianchi F, Bruno M, (in press) The Lesbos quarries: new archaeometrical and archaeological data, ASMOSIA 122018 - Interdisciplinary studies on Mediterranean ancient marble and stone - Proceedings of the Twelfth International Conference on the Study of Marble and Other Stones Used in Antiquity

Bianchi F (2009) Su alcuni aspetti della decorazione architettonica in marmo a Leptis Magna in età imperiale. Marmora 5:45-70

Bianchi F, Bruno M, Gorgoni C, Pallante P, Ponti G (2011) The pilasters of the Severan Basilica at Leptis Magna and the School of Aphrodisias: new archaeometrical and archaoeological data. In: Jockey P (eds) Asmosia 6, Levkos Lithos: Interdisciplinary studies on Mediterranean ancient marble and stone - Proceedings of the Sixth International Conference on the Study of Marble and Other Stones Used in Antiquity, Éditions Karthala, Paris, pp 329-349
Bianchi F, Bruno M, Pike S (2015) Pentelic marble in the Severan complex in Leptis Magna (Tripolitania, Libya). In: Pensabene P and Gasparini E, (eds) ASMOSIA 10: Interdisciplinary studies on ancient stone-Proceedings of the Tenth International Conference of the Association for the Study of Marble and Other Stones in Antiquity, Rome, pp 23-34

Bianchi F, Bruno M, Attanasio D, Prochaska W (2020) Leptis Magna e il marmo di Lesbo. Cave, manufatti e distribuzione. QuadALibya 23, n.s. III: $17-90$

Bianchi F, Bruno M, Attanasio D, Prochaska W, (in press) Leptis Magna and the Lesbos Marble, ASMOSIA 122018 - Interdisciplinary studies on Mediterranean ancient marble and stone Proceedings of the Twelfth International Conference on the Study of Marble and Other Stones Used in Antiquity

Boehm R, Master DM, Le Blanc R (2016) The basilica, bouleuterion, and civic center of Ashkelon. Am J Archaeol 120(2):271. https:// doi.org/10.3764/aja.120.2.0271

Bruno M, Bianchi F (2015) Marmi di Leptis Magna, Studia Archaeologica 204, Rome

Bruno M, Bianchi F, Attanasio D, Prochaska W (2021) Leptis Magna e il marmo di Lesbo. Cave, manufatti e distribuzione. Quaderni Storici 23:45-119

Burrell B (2018) Multiple reuse of imported marble pedestals at Caesarea Maritima in Israel, ASMOSIA 11, Interdisciplinary studies on ancient stone, Proceedings of the XI International Conference of ASMOSIA, Split, pp 117-122

Cramer T (2004) Multivariate Herkunftsanalyse von Marmor auf petrographischer und geochemischer Basis (diss.). Technischen Universität Berlin, Berlin

Dell'Acqua A (2013) The use of the heart-shaped pillar in the ancient architecture: examples and circulation. In: by Bombardieri L, D'Agostino A, Orsi V, Guarducci G, Valentini S (eds) SOMA 2012: identity and connectivity: Proceedings of the 16th Symposium on Mediterranean Archaeology, Florence, Italy, 1-3 March 2012, Volume 2, Oxford, pp 1139-1150

Dell'Acqua A (2021a) The Severan basilica of Ashqelon and its décor. In: Dell'Acqua A, Peleg-Barkat O (eds.), The basilica in Roman Palestine. Adoption and adaption processes, in Light of Comparanda in Italy and North Africa, pp 133-152

Dell'Acqua A (2021b) Roman Ascalon between land and sea. In: Kamlah J (ed) Lichtenberger A. Ancient Palestine and the Mediterranean, Abhandlungen des Deutschen Palästina-Vereins, pp 269-336

Dirven L (2011) The imperial cult in the cities of the Decapolis, Caesarea Maritima and Palmyra. A note on the development of imperial cults in the Roman Near East. ARAM 23:141-156. https://doi. org/10.2143/ARAM.23.0.2959654

Fischer M (1995) The basilica of Ascalon: marble, imperial art and architecture in Roman Palestine. J Roman Archaeol, Supplem Series 14:121-150

Fischer M (1998) Marble studies: Roman Palestine and the marble trade. With assistance of Z. Pearl, Tziona Grossmark. XENIA 40, UVK, Uni.-Verl. Konstanz

Fischer M (2002) Marble studies in Israel since Lucca 1988: a balance as the millennium turns. In: Lazzarini, L. (ed). Asmosia VI Conference, Interdisciplinary studies on ancient stone. Venice: $317-324$

Fischer M (2007) Marble imports and local counterparts: luxury business in Roman Palestine. Productions et échanges dans la Syrie grecque et romaine (Actes du colloque de Tours). Orient-Occident 8:249-269

Fischer M (2010) Greece and Rome in the Near East: general aspects, problematic and state of research in ancient Israel - introductory paper. Bollettino di Archeologia on line I 2010/ Volume speciale F / F8 / 1, pp 1-22 
Fischer M (2019) Greek and Roman impact in the Southern Levant: the architectural and artistic response. Marble as a cultural factor. Dossiê: 'Conexões mediterrânicas: Oriente e Ocidente através da História, Literatura e Arqueologia (Hélade 5.3), 13-44

Fischer M, Stein A (1994) Josephus on the use of marble in building projects of Herod the Great. J Jewish Stud 45:79-85

Floriani Squarciapino M (1966) Leptis Magna, Basel

Floriani Squarciapino M (1974) Sculture del Foro severiano di Leptis Magna, Roma

Friedland E A (2012) The Roman marble sculptures from the Sanctuary of Pan at Caesarea Philippi/Panias (Israel), Boston, pp. 21-34

Galili E, Sharvit J, Dahari U (2001) In: Sasson A, Safra Z, Sagiv N (eds) Ashqelon and the sea in light of the underwater and coastal archaeological findings. A city on the Seashore, Ashqelon, pp $11-38$

Ganor S, Bar-Nathan R (2021) The Tel Ashqelon Roman Basilica in light of renewed excavation: archaeological and stratigraphical considerations. In: Dell'Acqua A (eds), The basilica in Roman Palestine. Adoption and adaption processes, in Light of Comparanda in Italy and North Africa, pp 109-132

Johnson B L (2008) Ashkelon 2: imported pottery of the Roman and late Roman periods, Winona Lake/Indiana

Kislinger E (1999) Zum Weinhandel in frühbyzantinischer Zeit. Tyche 14:141-156

Kokkorou-Alevra G, Poupaki E, Efstathopoulos A, Kopanias K, Hadjikonstantinou A (2006) The ancient quarries of Prokonessos in Propontis. Archaeognosia 13:155-196 (in Greek)

Leka E, Zachos G (2015) The marmor Lesbium reconsidered and other stones of Lesbos. In: Pensabene P and Gasparini E, (eds) ASMOSIA 10: Interdisciplinary studies on ancient stone-Proceedings of the Tenth International Conference of the Association for the Study of Marble and Other Stones in Antiquity, Rome, pp 201-211

Matthews J (2006) The journey of Theophanes: travel, business and daily life in Roman East, New Haven

Musso L, Buccino L, Attanasio D, Bruno M, Prochaska W (2016) Marmo e scultura a Leptis Magna: un'analisi alla luce di nuovi dati archeometrici. Libya Antiqua 9:97-123

Musso L, Buccino L, Bruno M, Attanasio D, Prochaska W (2018) Marble and sculpture at Lepcis Magna (Tripolitania, Libya): a preliminary study concerning origin and workshops. In: Poljak D M and Marasović K, (eds) ASMOSIA 11: Interdisciplinary studies on ancient stone-Proceedings of the Eleventh International Conference of the Association for the Study of Marble and Other Stones in Antiquity, Split, pp 481-490

Pearl Z, Magaritz M (1991) Stable isotopes and the Roman marble trade-evidence from Scythopolis and Caesarea, Israel. In: Taylor H P, O'Neil J R, Kaplan I R (eds) Stable isotope geochemistry. A tribute to Samuel Epstein. With assistance of Samuel Epstein. San Antonio, Geochemical Society, Special publication, Geochemical Society 3: 295-303

Pensabene P (1977) Marmi d'importazione, pietre locali e committenza nella decorazione architettonica di età severiana in alcuni centri delle province Syria et Palestina e Arabia. Archeologia Classica 49:275-422
Pensabene P (2006) Le scuole di Nicomedia e Afrodisia e i pilastri della Basilica Severiana di Leptis Magna. Marmora 2:41-58

Pensabene P (2013) I marmi nella Roma Antica, Roma

Pensabene P, Rodà I, Domingo J Á (2015) Production and distribution of Troad granite, both public and private. In: Pensabene $\mathrm{P}$ and Gasparini E, (eds) ASMOSIA 10: Interdisciplinary studies on ancient stone-Proceedings of the Tenth International Conference of the Association for the Study of Marble and Other Stones in Antiquity, Rome, pp 311-322

Piéri D (2005) Le commerce du vin oriental à l'époque Byzantine. Beirut. Bibliothèque d'Archéologie et d'Histoire. Institut Français du Proche Orient

Prochaska W (2015) Fine-grained dolomitic marble of high sculptural quality used in antiquity. In: Pensabene P and Gasparini E, (eds) ASMOSIA 10: Interdisciplinary studies on ancient stone-Proceedings of the Tenth International Conference of the Association for the Study of Marble and Other Stones in Antiquity, Rome, pp 661-670

Prochaska W, Attanasio D (2021) The challenge of a successful discrimination of ancient marbles (part I): a databank for the marbles from Paros, Prokonnesos, Heraklea/ Miletos and Thasos. J Archaeol Sci Rep 35:1-8. https://doi.org/10.1016/j.jasrep.2020. 102676

Prochaska W, Attanasio D, Bruno M (2018) Unraveling the Carrara Göktepe entanglement. In: Poljak D M and Marasović K, (eds) ASMOSIA 11: Interdisciplinary studies on ancient stone-Proceedings of the Eleventh International Conference of the Association for the Study of Marble and Other Stones in Antiquity, Split, pp 175-185

Romano I B, Fischer M (2009) Roman marble and limestone sculpture from Beth Shean, Israel. In: Gaggadis-Robin V (ed) Les ateliers de sculpture régionaux: techniques, styles et iconographie, Aixen-Provence, pp 391-400

Romano IB, Tambakopoulos D, Maniatis Y (2021) A Roman portrait of Alexander the Great from Beth Shean. Israel Museum Stud Archaeol 10:2-29

Russell B (2013) The economics of the Roman stone trade. Oxford

Safrai Z (1994) The economy of Roman Palestine, London, New York

Stager LE, Schloen JD, Master DM (2006) Ashkelon 1: introduction and overview (1985-2006). Lake/Indiana, Winona

Walda H, Walker S (1988) Isotopic analysis of marble from Lepcis Magna: revised interpretations. Lybian studies 19:55-59

Ward Perkins JB (1951) Tripolitania and the marble trade. J Roman Stud 41:89-104

Ward Perkins J B (1993) The Severan buildings of Leptis Magna. An architectural survey, Society for Libyan Studies, Monograph No. 2, Tripoli

Publisher's note Springer Nature remains neutral with regard to jurisdictional claims in published maps and institutional affiliations. 